\title{
Assessing the use of Computer-based Assessment- Feedback in Teaching Digital Accountants
}

\author{
Akrum Helfaya, Ph.D. \\ Keele University, UK \\ $\&$ \\ Damanhour University, Egypt \\ a.n.ekara.helfaya@keele.ac.uk
}

This is the final peer reviewed version of the following article: [Helfaya, A. (2018) Assessing the use of Computer-based AssessmentFeedback in Teaching Digital Accountants. Accounting Education [https://doi.org/10.1080/09639284.2018.1501716]. This article may be used for non-commercial purposes in accordance with Accounting Education and Routledge Taylor \& Francis Group terms and conditions for self-archiving. 


\title{
Assessing the use of Computer-based Assessment- Feedback in Teaching Digital Accountants
}

\begin{abstract}
Both assessment and feedback have a vital impact on students' learning. Using computerbased assessment (CBA) with constructive and prompt computer-based feedback (CBF) reduces the attainment gap of the new generation of digital students. Action research methodology was employed to explore students' view of utilising CBA and/or CBF in teaching and learning practice. A survey was administered to 537 undergraduate students in the Management School of a British university to collect data about their perceptions of using CBA and CBF to assess their progress. Findings from students' survey show that students are generally appreciated the use of and benefits of CBA and/or CBF in teaching accounting modules. Findings also reveal that many participants valued working online compared to paper-and-pencil assessment and they also appreciated the timely and constructive feedbackfeedforward they received. Information technology (IT), therefore, can provide an innovative type of assessment and feedback that students' desire in an effective manner.
\end{abstract}

Keywords: teaching and learning; accounting education; computer-based assessment; computer-based feedback; digital accountants 


\section{Introduction}

\section{Research question}

Over the last three decades, integrating the World Wide Web (WWW) and technology into the accounting curriculum was used as a communication tool with the students and helping educators to design e-Assessment-Feedback to their students (see, Aisbitt \& Sanghster, 2005; Paisey \& Paisey 2004; Sangster \& Wilson, 1991; Sangster, 1992; Sangster \& Mulligan, 1997; Sangster \& Willson, 1991). Accordingly, e-Learning-Feedback has seen a vast growth in the last thirty years, and it is expected to continue in the future (Aisbitt \& Sangster, 2005; Bennett et al., 2008; Einig, 2013; Mihret et al., 2017; Nguyen et al., 2016; Pincus et al., 2017; Timmis et al., 2016). Over these thirty years, a significant discussion has been ascended about the features of the present's generation of students due to their intensive use of information technology (IT) and social media including, blogs, video sharing, Facebook, Twitter, Wikipedia, LinkedIn, etc., (Kirkwood \& Price, 2005; Simin \& Heidari, 2013; Thelwall, 2000), and the best way of involving digital citizens in higher education institutes (HEIs) (Al-Htaybat et al., 2018; Beukes et al., 2017; Bullen et al., 2011; Jones et al., 2010; Pincus et al., 2017). Recent studies reveal that the main reason is that regular use of IT in everyday indicates that skilled digital citizens are able to transmit their knowledge and experience to teaching and learning activities (e.g. Al-Htaybat et al., 2018; Beukes et al., 2017; Gros et al. (2012). In fact, we cannot ignore that using IT in teaching and learning in higher education (T\&L in HE) as a key factor to meet the expectations of "digital natives" (Aisbitt \& Sanghster, 2005; Duff, 1998; Jones et al., 2010; Kirkwood \& Price, 2005; Oblinger \& Oblinger, 2005; Sangster, 1996; Simin \& Heidari, 2013; Thelwall, 2000).

This action research (AR), therefore, investigates how students perceive and assess the use of computer-based assessment (CBA) and/or computer-based feedback (CBF) in the teaching of their accounting modules. 


\section{Importance of the research}

Investigating students' perception of using CBA and/or CBF in teaching accounting modules is timely as both accounting educators and professionals worldwide are faced with the challenges of pedagogical innovation in teaching digital natives in the $21^{\text {st }}$ Century (see, Barbera, 2009; Bullen et al., 2011; Jebeile \& Abeysekera, 2010; Kirkwood \& Price, 2005; Litherland et al., 2013). Mihret et al. (2017), for example, reported that IT in an e-learning environment and assessment practice will inspire and assist learners to improve their learning as well as provide educators with feedback about the effectiveness of their T\&L approaches (see, Aisbitt \& Sangster, 2005; Barbera, 2009; Helsper \& Eynon, 2010; Nguyen et al., 2016; Timmis et al., 2016). Similarly, Race (2005) stated that educators find that online feedback will speed up the process of providing timely and constructive feedback. Further, lecturers can use both $\mathrm{CBA}$ and $\mathrm{CBF}$ to provide students with timely information on their academic progress, and to diagnose and analyse their weaknesses and strengths (Clariana \& Wallace, 2002; Duff, 1998; Ecclestone \& Pryor, 2003; Evans, 2013; Sangster, 1996).

In the same vein, JISC $(2010,5)$ states that "Assessment lies at the heart of the learning experience: how learners are assessed shapes their understanding of the curriculum and determines their ability to progress. Both assessment and feedback form a significant part of practitioners' workloads and, with increased numbers, reduced budgets and higher learner expectations, continue to be a matter of concern for many institutions". In practice, the accounting group in the Management School of a British university is still using the traditional paper-and-pencil assessment and very late handwritten feedback on these types of assessment-feedback. With the possibility that using computer-based assessment and feedback (CBAF) may shape learners' expectations and engagements in the T\&L process (Aisbitt \& Sangster, 2005; Bennett et al., 2008; Crook et al., 2006; Einig, 2013; Marriott \& Teoh, 2012a; Litherland et al., 2013; McDonald, 2002), the accounting group initiated the 
use of IT in teaching accounting modules ${ }^{1}$ using CBAF. For example, at a macro level, both universities and students asked teaching $\mathrm{Staff}^{2}$ for more diverse assessments with instant electronic feedback. While at a micro level, accounting department, professional bodies such as ACCA, CIPFA and CIMA start to use CBA at various levels (Al-Htaybat et al., 2018; Aisbitt \& Sangster, 2005; Rodrigues et al., 2018). Finally, at a meso level, the accounting group believes that adopting CBAF may lead to improve students' engagement, reduce attainment gap, and help to introduce new specialised computerised accounting programmes and modules. So, in 2013 the accounting group started with Year 2 accounting module: Intermediate Financial Accounting. In doing so, the module leader, developed a series of questions in relevant pools to be selected from, to create a CBAF for this module. Progressively more CBAFs were designed and delivered by other accounting colleagues.

\section{Answering the research question}

In light of the above, this research aims to assess the students' perceptions of the use of CBAF received on their T\&L process and academic performance respectively. In doing so, an AR methodology was used to provide an in-depth understanding of how undergraduate students experience their CBA and CBF practice. An online survey was designed based on previous literature (e.g. Einig, 2013; Jebeile \& Abeysakra, 2010; Ltherland et al., 2013; Loewenberger \& Bull, 2003; Marriott \& Teoh, 2012a; O’Connell et al., 2010; Rowe \&

\footnotetext{
${ }^{1}$ In HEls, a module is a self-contained course that normally lasts for one academic semester and covers just one subject (e.g. cost accounting, international financial reporting, corporate governance, digital marketing, etc.). It is assessed independently of other modules. Accordingly, the academic year is divided up into two semesters and the students need to study a number of predetermined modules. The student's final degree qualification is based on selecting and passing a predetermined number of modules (see, QAA, 2009; Cottrell, 2013).

2 In HEls, teaching staff refer to professional and qualified persons such as 'Lecturers', 'Teaching Fellows', 'Tutors', or 'Teaching Assistants' who are directly involved in the teaching and learning process and worked with students as a whole class in a lecture theatre, in small groups in labs/classroom, or beyond the classroom (Cottrell, 2013).
} 
Wood, 2008) and then distributed via the virtual learning environment (VLE) ${ }^{3}$ to 537 undergraduate students studying accounting modules.

\section{Contribution of the research}

This research describes a case study where CBAF was introduced into some accounting modules at a Management School of a British university. There is no doubt that the use of CBAF is one of the fastest areas of growth in accounting education literature (see, Einig, 2013; Massoudi et al., 2017; Mihret et al., 2017; Litherland et al., 2013). However, their potential to accounting educators' practice worldwide remains yet to be explored for teaching the digital accountants in the digital age in general, with few exceptions (see, Aisbitt \& Sangster, 2005; Al-Htaybat et al., 2018; Marriott, 2009; Marriott \& Lau, 2008; Marriott \& Teoh, 2012a, 2012b). Additionally, the accounting professional bodies such as ACCA, CIMA and CIPFA started to adopt CBA at various levels of their qualifications (see, Al-Htaybat et al., 2018; Aisbitt \& Sangster, 2005; Rodrigues et al., 2018). Our study, therefore, extends the limited literature on CBAF in accounting education by providing evidence of how undergraduate students perceive and prefer the use of CBAF in assessing their academic progress to paper-and-pencil assessment and delayed handwritten feedback. Further, the findings contribute to accounting education knowledge in the $21^{\text {st }}$ Century by illustrating the role of CBAF in enhancing learner learning and filling the attainment gap and therefore the development of employability skills in the digital future (Einig, 2013; Litherland et al., 2013; Massoudi et al., 2017).

This research also provides evidence that the principles of using IT innovation to integrate eAssessment with e-Feedback-feedforward to assess students' performance and to provide

\footnotetext{
3 VLE is an online learning space provided by the University for organising learning resources (e.g. programmes/modules handbooks, lectures' notes, tutorials' questions, reading list, etc.) for the university, faculty or school, usually with specific space for each programme of study (Cottrell, 2013).
} 
timely and detailed feedback-feedforward report on their academic achievements and to diagnose and analyse their strengths and weaknesses. According to the limited CBA literature in accounting education, most studies investigated the students' perceptions of the benefits, challenges and applicability of using CBA in specific accounting module (e.g. financial accounting, management accounting, or auditing courses for specific year (e.g. first, second, or third year) (see, Aisbitt \& Sangster, 2005; Einig, 2013; Jebeile \& Abeysakra, 2010; Massoudi et al., 2017; Ltherland et al., 2013; Marriott, 2009; Mihret et al., 2017; Sangster, 1992). This way of using a module case (i.e. one group-analysis) or a single year (i.e. firstyear students) still seems to give some more meaningful findings for the students perceptions of using the innovative CBA/CBF compared to the traditional paper-and-pencil assessment and feedback (e.g. Aisbitt \& Sangster, 2005; Sangster, 1992). However, the analysis does not enable us to see any statistical significant differences in the students' perception of using CBA/CBF between different accounting modules and level of study.

On the contrary, this research contributes to accounting education knowledge by adopting the three group-analysis by comparing the students' perception of the use of CBFA in T\&L three accounting modules at the three levels of the undergraduate study. This three group-analysis enables us to see if there any effect of the level of study (i.e. Year 1, Year $2 \&$ Year 3) in the student's perception of adopting CBAF in accounting education. Generally, the findings show that there is no statistical difference among the three groups in perceiving the importance of using CBAF in teaching accounting modules. This means that the students' favourable perceptions regarding of the relative advantage, compatibility and ease of using CBAF, compared to paper-and-pencil assessment and feedback, are not affected by the level of their study or their academic experience. 


\section{Structure of the research}

The reminder of this research proceeds as follows. Section 2 reviews the literature on assessment and feedback, and then considers the CBAF and its impacts in T\&L future accountants. The AR methodology is presented in section 3. The results are reported and discussed in section 4. Section 5 discusses and concludes research.

\section{Literature review}

\section{Assessment and Feedback}

A review of the literature on assessment and feedback that has published in the 1990's volumes of three leading accounting education journals (Accounting Education, Issues in Accounting Education, and Journal of Accounting Education) increase emphasis on T\&L in HE towards using technology-based course materials for learning and assessment-feedback purposes (Duff, 1998; Sangster, 1996; Paisey and Paisey, 2004). In T\&L in HE, assessment and feedback are two sides of the same coin of evaluating the academic progress of and giving feedback to learners (Abbott \& Palatnik, 2018; Clariana \& Wallace, 2002; Duff, 1998; Sangster, 1996; Thelwall, 2000; Van der Kleij et al 2015). According to O’Connell et al. (2010) the assessment system is that the dominant influence on the method students learn and acquire new knowledge and skills (Clariana \& Wallace, 2002; Rust et al., 2005). Formative assessment, for example, involves teachers and students responding to students' work with the intention of modifying it to assist the student to evaluate her/his attainment and to achieve better improvement in the future (Barbera, 2009; Crook et al., 2006; Massoudi et al., 2017; Pryor \& Crossouard, 2008; O'Connell et al., 2010). Formative assessment, therefore, could be a learning method that drives to control and monitor the loss meaning practiced by learners during the T\&L process (Pryor \& Crossouard, 2008). 
Accordingly, the most effective assessment is one which is planned and combined to the teaching approach, written within the early stage of coming up with the programme and remote-controlled by the method of formative assessment and given instant feedback (Bailey \& Garner, 2010; Ecclestone \& Pryor, 2003). Similarly, Rust et al. (2005) identify three aspects in a very constructive assessment system: a) clear association between learning method and outcomes; b) specific assessment criteria in hand by lecturers and students, and c) a feedback method during which students are actively concerned.

Feedback is viewed as one of the most powerful tools to enhance students' learning (Van der Kleij et al., 2015; Sadler, 1989). Hattie and Timperley (2007, 81) defined feedback as “information provided by an agent (e.g. teacher, peer, book, parent, self, experience) regarding aspects of one's performance or understanding”. Feedback provided to learners can help reduce the attainment gap between the current and the intended learning outcomes (Hattie \& Timperley, 2007; Sadler, 1989). However, to enhance the usefulness of the assessment process in $\mathrm{T} \& \mathrm{~L}$ practice, the conjunction of lecturer and leaner perceptions and experiences of providing feedback is needed (Bailey \& Garner, 2010; Evans, 2013; Hattie \& Timperley, 2007; O’Connell et al., 2010). In practice, a conflict could arise as a result of completely different perceptions of feedback between lecturer (i.e. preparer of feedback report) and learner (i.e. user of feedback report) (Carless, 2006; Van der Kleij et al., 2015). Sadler (1989) identifies that to push learning, feedback needs students to possess a conceptualisation of the target performance, be able to compare actual performance with the target one, and take actions to fill this attainment gap.

To conclude, assessment ascertains what is taught and how it is learnt and how learners' academic performance is often assessed (Abbott \& Palatnik, 2018; Marriott \& Teoh, 2012a; Mihret et al., 2017; Nguyen et al., 2016). Whereas feedback on assessment/test may be a passage for facilitating learner self-assessment, gaining knowledge and experience, and 
inspiring motivations that lecturers will use to form and/or reform teaching and learning method (Carless, 2006; Gibbs \& Simpson, 2005; Hattie and Timperley, 2007; Van der Kleij et al., 2015). Consequently, good practice of assessment and/or feedback in T\&L in HE may be a method within which lecturers have peer dialogues with their students and students are actively engaged with their lecturers in the T\&L process (Crook et al., 2006; Evans, 2013; Timmis et al., 2016). Further, instant and constructive feedback could reduce the gap between the actual and students' target performance and is additionally thought of to be a collectively owned system that is self-generated, handy and active (e.g. Hattie \& Timperley, 2007; Torrance \& Pryor, 2001; Van der Kleij et al., 2015).

\section{Computer-based Assessment and Feedback}

Integrating the WWW and IT into the accounting curriculum received a considerable attention in the first years of issuing this journal, Accounting Education (Paisey \& Paisey, 2004). For example, Alan Sangster and his co-author(s) have a research track record of embedding technology into accounting education and published highly rated accounting education papers between 1990 and 2005. For example, Sangster \& Wilson (1991) and Sangster $(1992 ; 1995)$ introduced some expert systems to some accounting courses and examined the impact of these expert systems on the accounting education and the way of developing students; conceptual, technical and understanding of information system if they were to be able to produce accounting information in a changeable context (see, also, Brown et al., 1995; Duff, 1998; Paisey \& Paisey, 2004; Sangster, 1996; Sangster \& Lymer, 1998; Sangster \& McCombie, 1993; Sangster \& Mulligan, 1997). They also investigated the effectiveness of computer-assisted learning, including e-Assessment as an alternative to existing teaching methods in the new educational era (e.g. Aisbitt \& Sangster, 2005; Duff, 1998; Sangster, 1992, 1996; Sangster \& Lymer, 1998). They found that a positive relationship between student performance and the use of e-Assessment. They also stated that 
using computer-based instruction and e-Assessment in accounting education may be a practical alternative to traditional teaching methods and paper-and-pencil assessment and to reduce the attainment gap as well (see, Aisbitt \& Sangster, 2005; Brown et al., 1995; Duff, 1998; Sangster, 1996).

Accordingly, the importance of assessment and feedback in the T\&L process in HE is widely acknowledged especially with the growing popularity of the e-Assessment-Feedback for learning approaches in the digital age (Al-Htaybat et al., 2018; Van der Kleij et al., 2015; Mihret et al., 2017). Both assessment and feedback are the centre of discussion among the foremost Great Britain and Northern Ireland higher instructional establishments since the publishing of National Student Survey (NSS) in 2005 (Marriott \& Teoh, 2012b; O'Connell et al., 2010). According to the last eight NSSs, the results show that student satisfaction scores for both assessment and feedback were below alternative aspects of students' experiences in HE. However there are several attempts are created to boost assessment and feedback, they ignored a number of the main challenges long faced by HEIs. For instance: a) mass education; b) modularisation and semesterisation; c) student consumerism; d) huge cuts publically funding, and e) digital natives (learners), are among these challenges (Marriott \& Teoh, 2012b, 4; see, also, McDonald, 2002; Timmis et al., 2016).

Responding to these five challenges, IT may well be accustomed highlight the advantages and challenges of using $\mathrm{CBAF}$ in $\mathrm{T} \& \mathrm{~L}$ practice. CBAF, therefore, offers an innovative approach compared to paper-and-pencil assessment and feedback (Aisbitt \& Sangster, 2005; Helsper \& Eynon, 2010; Litherland et al., 2013; Timmis et al., 2016). Students work on assignments/exams as common, but, their files are assessed via VLE instead of a paper-andpencil assignments and feedback. CBAF is pre-designed and developed by the module leader and so created, delivered and marked using a computer (Clariana \& Wallace, 2002; Litherland et al., 2013; McDonald, 2002; Marriott \& Teoh, 2012a; Wong, 2009). The 
possibility to boost considerably the T\&L process and its outcomes for learners in a wide selection of programmes using IT in both assessment and feedback have been reported (JISC, 2007; Marriott \& Teoh, 2012a; Wong, 2009). By making an innovative online assessmentfeedback practices, learners' engagements and motivations well be improved (Litherland et al., 2013; Wong, 2009). They will be able to know their weaknesses and strengths, assess their progress, and improve their study skills (e.g. Lews \& Sewell, 2007; Marriott \& Lau, 2008; Marriott, 2009; Race, 2005). Additionally, Simin \& Heidari (2013) stated that CBAF is not prone to human error, saves staff time including supervising and marking, reduces printing costs, monitors the students' progress, and provides timely and constructive feedback.

In spite of the above advantages of using CBAF, there are some disadvantages. For example, using a CBAF can be costly for buying specific hardware and software, time-consuming for preparing the questions bank/pools and detailed feedback, required IT training to the teaching staff, and the students' need to have sufficient IT skills and experience of practicing CBA (see, Aisbitt \& Sangster, 2005; Litherland et al., 2013; Simin \& Heidari, 2013). In the same vein, McDonald (2002) stated that both computer familiarity and anxiety would be expected to affect the use of computers for T\&L purposes such as assessing students' performance using CBAF. He stated that students who had less computer familiarity performed worse on CBA (see, also, Lee, 1986; Taylor et al., 1999). While computer anxiety defined as "the fear experienced when interacting with a computer or anticipating an interaction" (McDonald, 2002, 305). This computer anxiety has contended that to overlap with computer familiarity/experience (McDonald, 2002; Powers, 1999). Thus, the computer anxiety results from a lack of familiarity and experience with using computers (see, for more details, Lee, 1986; McDonald, 2002; Powers, 1999; Taylor et al., 1999). Despites all these disadvantages, teaching staff in HEIs see CBAF as being a very effective assessment-feedback tool to assess 
the progress of their digital natives (see, Kirkwood \& Price, 2005; Litherland et al., 2013; McDonald, 2002; Simin \& Heidari, 2013).

In brief, teaching staff ought to assess students' progress using different types of assessments as no single assessment type will determine whatever all standards are achieved or not. These different assessment's types may be a keystone to assist lecturers to assess their students' academic progress. Comparing to old assessment paradigm, a multiple assessment one is needed to valid, credible, and honest data concerning students' performance (Evans, 2013; Timmis et al., 2016). As a result, the online assessment-feedback is one in this entire multiple assessment paradigm to gauge the accomplishment and monitor the performance of our "Net Generation" in "the Digital Age" within the "T\&L beyond the classroom context". This research, therefore, aims to identify the current practice in using CBAF in accounting education, setting strategies to raise awareness of good practice and to embed good practice into both accounting and non-accounting programmes at HEIs. The overall objective is to achieve a discipline-wide improvement in CBA and/or CBF practices. To this end, the main research question is developed to investigate the perception of the development and use of CBA and/or CBF of the undergraduate accounting students in their T\&L process, as follows:

\section{How do students assess the use of CBA and/or CBF in T\&L accounting modules?}

\section{Action research methodology}

According to Baker \& Logan (2006), the AR is the appropriate methodology to conduct the accounting education research (see, also, Abbott \& Palatnik, 2018; Cohen et al., 2005; Doran et al., 2011; Hughes, 1997). They stated that "AR focuses on a problem, or particular practice, occurring within a specific social setting. The purpose of AR is to alleviate the problem, or increase the effectiveness of the practice", (Baker \& Logan, 2006, 4). This study, therefore, is exploratory in nature and part from a large AR project. This is a case 
study aiming to collect quantitative data by asking students to complete an online survey to reflect their perceptions of using CBA and CBF in T\&L accounting modules. More details are explained in turn.

\section{Rationale of using Action Research}

AR has been defined in T\&L environment as "an approach to improving education through change, by encouraging teachers to be aware of their own practice, to be critical of that practice and to be prepared to change it" (McNiff, 1988, 4; see, also, Baker \& Logan, 2006; Carr \& Kemmis, 1986; Doran et al., 2011; Torrance \& Pryor, 2001). In the same vein, Paisey \& Paisey (2003) state that AR method is suited to investigate T\&L practices in classrooms as it can be conducted by people (e.g. teachers and students) and for improving their T\&L practices. Also, Hughes (1997) states that AR is not a single approach, but rather a combination of doing research using multiple approaches and acting on it to change current practices at the same time. While Elliott (1991) argues that AR projects aim to improve practice rather than to add a contribution to the knowledge by linking the gap between research and teaching. Additionally, Saunders et al (2009) state that AR is used to solve practical issues where the researcher is part of the research environment and of the changes taking place. AR, therefore, is a practical and actionable methodology to the professional investigation in any social situation (Abbott \& Palatnik, 2018; Cohen et al., 2005; Doran et al., 2011; Hughes, 1997; McNiff, 1988).

As its name proposes, AR concerns actors- those people carrying out their professional works (e.g. Teachers, Accountants, and Doctors) from day to day- and aims to understand and improve those works. AR in education, for example, is grounded in the working lives of teachers, as they practise them. Carr \& Kemmis (1986) state that AR is about improving: a) practice; b) understanding of actual practice, and c) the situation in which the practice takes place. Similarly, Kember (2000) ascertains that AR project is concerned with social practice, 
improving current $\mathrm{T} \& \mathrm{~L}$ methods and encompasses active contribution by participants. In such a systematic AR study a smooth transition between four steps from: 1) project planning; 2) intervention(s); 3) observing how the interventions have affected the participants to 4) project reflection is required (Kember, 2000; see, also, Baker \& Logan, 2006; Kember \& Young, 2006; McNiff, 1988; Torrance \& Pryor, 2001).

However, an AR centres on the practitioners (e.g. teaching staff), the views of the students are paramount in terms of the success of the current $\mathrm{T} \& \mathrm{~L}$ practice, or the required changes to improve this practice (Abbott \& Palatnik, 2018; Hughes, 1997; Paisey \& Paisey, 2003). For this research, an AR method was justified by the active participation of the "Net Generation $H E$ students" we teach them at the management school whereas they study Accounting and/or relevant Business degrees (see, Baker \& Logan, 2006; Saunders et al., 2009). With regard to the use of $\mathrm{CBAF}$ in the T\&L process, it would be very difficult to evaluate the perception and effectiveness of using CBAF without the involvement of students in the AR process. The undergraduate students, therefore, were believed to be representative of current management school and HE students (see, Nguyen et al., 2016). In this AR study, 537 students taking accounting modules were surveyed to assess their perceptions of the use and effectiveness of CBA and/or CBF in the T\&L process ${ }^{4}$.

\section{Action Research Sample and Method}

The AR sample comprises all 2015-16 undergraduate accounting modules which adopt $\mathrm{CBAF}^{5}$ in teaching and learning accounting, namely (the syllabuses for these Accounting modules are available in Appendix 1):

\footnotetext{
${ }^{4}$ Examples of these CBA questions (e.g. multiple-choice, true/false, calculation and essay questions such as define, list, describe, classify, explain, etc.) and CBF reports (e.g. feedback on correct/incorrect answers and feedforward) are available in Appendix 2.

5 These CBAs were designed using VLE features and accessible only to students taught these accounting modules. The students had access to their CBA via VLE using their university's usernames and passwords. Due to the big number of first-year students and the overall grade of the UG degree is based on the performance of second- and third-year only, the first-year students were taking their Accounting Principles' CBA on/offcampus. We gave them access to their CBA anytime, anywhere and one-entry for 5 working days. While
} 
1. Accounting Principles (Year 1: 291 Students)

2. Intermediate Financial Accounting (Year 2: 169 Students)

3. Advanced Financial Reporting (Year 3: 77 Students)

To develop the online survey, the existing literature related to CBA (e.g. Loewenberger \& Bull, 2003; Marriott \& Lau, 2008; Marriott \& Teoh, 2012a, 2012b) and CBF (e.g. Marriott \& Teoh, 2012a, 2012b; O’Connell et al., 2010; Rowe \& Wood, 2008) was reviewed. For example, the online assessment and online feedback of Marriott and Teoh (2012a) included questions on assessment and feedback. Their outlining of aspects of CBAF regarding benefits, views of working online, relevance and occurrence of CBA and/or CBF was informative. Rowe \& Wood's (2008) survey included students' perceptions, value and preferences for feedback. O'Connell and his Associates (2010) developed students' survey to explore feedback practices in Australian undergraduate accounting education. The students' survey was used as a diagnostic tool to identify the current and best practice of giving feedback to accounting education and to raise awareness of best practice in Australian Universities. Based on the above, the students' online survey was developed as follows:

- Section 1 was designed to collect demographic information from students relating to their university degree, year of study, gender, age, English as a first language, and student status.

- Section 2 required students to rate 5 specific statements on the view of working online.

- Section 3 asked students to rate 15 specific statements on the online tests on a scale in relation to their own perception of the use of online tests in accounting modules.

- Section 4 asked students to answer 5 questions about the usefulness and occurrence of online tests in accounting modules. 
- Section 5 required students to rate 8 specific statements on the online feedback in relation to their own perception of the given feedback in accounting modules.

- Section 6 gave students a free space to add any other comments (e.g. their experience of and desirable formats of $\mathrm{CBA} / \mathrm{CBF}$ ) on $\mathrm{CBA}$ and/or $\mathrm{CBF}$ that they would like to make.

Prior to finalisation, 2 staff reviewed the survey instrument. It was then pilot tested on a small sample of students. Based on this feedback, minor changes were made to the structure, sequence and content of the online survey. The student online survey was delivered through VLE to 537 undergraduate students studying an accounting module at first ( $n=291)$, second $(n=169)$, and third $(n=77)$ year of semester 1 in the academic year 2015-16, with 288 of these being useable (54\% response rate). To test the reliability of the online survey, the internal consistency method was applied to the collected data by using Cronbach's Alpha ${ }^{6}$. By running this test on the entire current survey questions, other than the respondent's demographic information and last section, the results of the reliability test shows that there is a reasonable degree of reliability - the overall reliability scale is $>0.7$.

\section{Results}

This section analyses and discusses the separate resulting data of students' online survey (i.e. Year 1, 2 \& 3), and then combining them into a single cohort. Additionally, all the findings will be reported and related to the relevant literature. To undertake comparative analysis across the three undergraduate students' groups (i.e. Year 1, $2 \& 3$ ), the results of the responses for each group will be considered. For this, the non-parametric Kruskal-Wallis test

\footnotetext{
${ }^{6}$ Cronbach's Alpha is the most common measure of reliability scale. It essentially calculates the average of all possible split-half reliability coefficients, with an indication that the acceptable value is $0.7-0.8$ (see, for more details, Field, 2013).
} 
was used because the current data (i.e. the 288 responses) fails the test of normality. This test was also used because there were more than two groups of data.

\section{Respondents' Demographic Information}

Section 1 was designed to collect students' demographic information (such as year of study, university degree, gender, age, English as a first language, and student status). As shown in Table 1 below, the overall demographic information revealed the following about the sample. The majority of students (62\%) were enrolled in accounting/accounting and finance programmes. For $50 \%$ of students, Male was their gender; $77.6 \%$ were 21 years old or under; $48 \%$ of students, English was not their first language, and $51 \%$ consisted of Overseas students. As first, second and third-year students across the school were included in the survey, the analysis required a breakdown between those enrolled in an accounting degree and those in other non-accounting degrees and other demographic information as presented in Table 1 below. 
Table 1: Respondents' Demographic Information

\begin{tabular}{|c|c|c|c|c|}
\hline Demographic Information & Year 1 (\%) & Year 2 (\%) & Year 3 (\%) & Total (\%) \\
\hline \multicolumn{5}{|l|}{ Q1. Undergraduate Degree: } \\
\hline - Accounting/Accounting \& Finance & $45(35)$ & $78(75)$ & $55(100)$ & $178(62)$ \\
\hline - Non-Accounting/Accounting \& Finance & $79(61)$ & $22(21)$ & $0(0)$ & $101(35)$ \\
\hline - No answer & $5(4)$ & $4(4)$ & $0(0)$ & $9(3)$ \\
\hline Total (\%) & $129(100)$ & $104(100)$ & $55(100)$ & $288(100)$ \\
\hline \multicolumn{5}{|l|}{ Q2. Gender: } \\
\hline - Male & $67(52)$ & $52(50)$ & $25(46)$ & $144(50)$ \\
\hline - Female & $54(42)$ & $47(45)$ & $26(47)$ & $127(44)$ \\
\hline - Would rather not respond & $8(6)$ & $5(5)$ & $4(7)$ & $17(6)$ \\
\hline Total (\%) & $129(100)$ & $104(100)$ & $55(100)$ & $288(100)$ \\
\hline \multicolumn{5}{|l|}{ Q3. Age: } \\
\hline-21 years or under & $111(86)$ & $78(75)$ & $34(62)$ & $223(77.6)$ \\
\hline - 22- 25 years & $8(6)$ & $18(17)$ & $17(31)$ & $43(15)$ \\
\hline - 26- 30 years & $1(1)$ & $1(1)$ & $0(0)$ & $2(0.7)$ \\
\hline - Over 30 years & $1(1)$ & $1(1)$ & $0(0)$ & $2(0.7)$ \\
\hline - Would rather not respond & $8(6)$ & $6(6)$ & $4(7)$ & $18(6)$ \\
\hline Total (\%) & $129(100)$ & $104(100)$ & $55(100)$ & $288(100)$ \\
\hline \multicolumn{5}{|l|}{ Q4. English (as a first language): } \\
\hline - Yes & $69(53)$ & $38(36)$ & $24(44)$ & $131(46)$ \\
\hline - No & $52(41)$ & $59(57)$ & $28(51)$ & $139(48)$ \\
\hline - Would rather not respond & $8(6)$ & $7(7)$ & $3(5)$ & $18(6)$ \\
\hline Total (\%) & $129(100)$ & $104(100)$ & $55(100)$ & $288(100)$ \\
\hline \multicolumn{5}{|l|}{ Q5. Status: } \\
\hline - UK student & $57(44)$ & $39(37)$ & $24(44)$ & $120(42)$ \\
\hline - EU student & $2(2)$ & $1(1)$ & $0(0)$ & $3(1)$ \\
\hline - Overseas student & $63(49)$ & $56(54)$ & $28(51)$ & $147(51)$ \\
\hline - Would rather not respond & $7(5)$ & $8(8)$ & $3(5)$ & $18(6)$ \\
\hline Total (\%) & $129(100)$ & $104(100)$ & $55(100)$ & $288(100)$ \\
\hline
\end{tabular}

\section{Respondents'Views of Working Online}

Section 2 asked students to rate 5 specific statements on the view of working online ranging from 1 (strongly disagree) to 5 (strongly agree). Table 2 below shows that the majority of students across the three years were agreed and most agreed with working online, preferring computer rather than paper-and-pencil exam, and computer marking (with overall 5-point means of 4.45, 4.10 and 3.90 respectively). For the last two items, paper-and-pencil exams are fairer than others and some students prefer CBA than others, Year 3 students are more 
agreed/ most agreed (41\% \& 38\% respectively) than year $1 \& 2$ students ( $27 \& 39$ and $30 \&$ 38 respectively). However, about $48 \% \& 32 \%, 52 \% \& 30 \%$ and $41 \% \& 35 \%$, of Year 1 , Year $2 \&$ Year 3 respectively, neither agree nor disagree about these two items. Table 2 below shows that the asymptotic values (Asymp. Sig) are more than 0.05 in every instance; this means that the students' perceptions of working online are not affected by the students' year groups. These results are consistent with prior literature in T\&L in HE (e.g. JISC, 2007; Marriott, 2009; Marriott \& Teoh, 2012a; Potter \& Johnston, 2006; Wong, 2009). 
Table 2: Respondents' Views of Working Online

\begin{tabular}{|c|c|c|c|c|c|c|c|c|c|c|c|c|c|c|c|c|c|c|c|}
\hline \multirow{3}{*}{ Statements } & \multicolumn{5}{|c|}{ Year 1 Group $(n=129)$} & \multicolumn{5}{|c|}{ Year 2 Group $(n=104)$} & \multicolumn{5}{|c|}{ Year 3 Group $(n=55)$} & \multicolumn{2}{|c|}{$\begin{array}{c}\text { Total Respondents } \\
\quad(\mathrm{n}=\mathbf{2 8 8}) \\
\text { Year 1, } 2 \text { \& } 3\end{array}$} & \multicolumn{2}{|c|}{ Kruskal-Wallis Test } \\
\hline & \multicolumn{3}{|c|}{ \% of Useable Responses } & \multirow[b]{2}{*}{$\begin{array}{l}5- \\
\text { Point } \\
\text { Mean }\end{array}$} & \multirow[b]{2}{*}{$\begin{array}{l}\text { Std. } \\
\text { Dev }\end{array}$} & \multicolumn{3}{|c|}{ \% of Useable Responses } & \multirow[b]{2}{*}{$\begin{array}{l}5- \\
\text { Point } \\
\text { Mean }\end{array}$} & \multirow[b]{2}{*}{$\begin{array}{l}\text { Std. } \\
\text { Dev }\end{array}$} & \multicolumn{3}{|c|}{ \% of Useable Responses } & \multirow[b]{2}{*}{$\begin{array}{l}5- \\
\text { Point } \\
\text { Mean }\end{array}$} & \multirow[b]{2}{*}{$\begin{array}{l}\text { Std. } \\
\text { Dev }\end{array}$} & \multirow[b]{2}{*}{$\begin{array}{l}5- \\
\text { Point } \\
\text { Mean }\end{array}$} & \multirow[b]{2}{*}{$\begin{array}{l}\text { Std. } \\
\text { Dev }\end{array}$} & \multirow[b]{2}{*}{$\mathbf{X}^{2}$} & \multirow[b]{2}{*}{$\begin{array}{l}\text { Asymp. } \\
\text { Sig }\end{array}$} \\
\hline & $\begin{array}{r}\mathrm{A} / \mathrm{SA} \\
\mathbf{4 - 5}\end{array}$ & $\begin{array}{l}\mathbf{N} \\
\mathbf{3}\end{array}$ & $\begin{array}{c}\text { SD/D } \\
1-2\end{array}$ & & & $\begin{array}{l}\mathbf{A} / \mathrm{SA} \\
\mathbf{4 - 5}\end{array}$ & $\begin{array}{l}\mathbf{N} \\
\mathbf{3}\end{array}$ & $\begin{array}{r}\text { SD/D } \\
1-2\end{array}$ & & & $\begin{array}{l}\mathbf{A} / \mathrm{A} \\
4-5\end{array}$ & $\begin{array}{l}\mathbf{N} \\
\mathbf{3}\end{array}$ & $\begin{array}{c}\mathrm{SD} / \mathrm{D} \\
1-2\end{array}$ & & & & & & \\
\hline Q1. I am happy with working online & 92 & 7 & 1 & 4.47 & 0.771 & 89 & 9 & 2 & 4.42 & 0.844 & 90 & 6 & 4 & 4.47 & 0.857 & 4.45 & 0.812 & 0.432 & 0.806 \\
\hline $\begin{array}{l}\text { Q2. I would prefer to take my } \\
\text { exams/tests on a computer rather than } \\
\text { on paper }\end{array}$ & 71 & 25 & 4 & 4.17 & 0.977 & 70 & 23 & 7 & 4.13 & 1.049 & 63 & 22 & 15 & 3.82 & 1.156 & 4.10 & 1.044 & 4.058 & 0.131 \\
\hline $\begin{array}{l}\text { Q3. Computer marking is more } \\
\text { consistent and reliable than human } \\
\text { marking }\end{array}$ & 60 & 35 & 5 & 3.92 & 1.043 & 58 & 31 & 11 & 3.91 & 1.183 & 53 & 33 & 14 & 3.78 & 1.134 & 3.90 & 1.110 & 0.793 & 0.673 \\
\hline $\begin{array}{l}\text { Q4. Paper-and-pencil exams/tests are } \\
\text { fairer than online exams/tests }\end{array}$ & 27 & 48 & 25 & 3.25 & 1.166 & 30 & 52 & 18 & 3.40 & 1.235 & 41 & 41 & 18 & 3.55 & 1.168 & 3.40 & 1.200 & 3.304 & 0.192 \\
\hline $\begin{array}{l}\text { Q5. Online tests favour some students } \\
\text { more than others }\end{array}$ & 39 & 32 & 28 & 3.41 & 1.310 & 38 & 30 & 32 & $\mathbf{3 . 3 1}$ & 1.352 & 38 & 35 & 27 & 3.30 & 1.383 & 3.40 & 1.335 & 0.351 & 0.840 \\
\hline
\end{tabular}

5-Point Likert scale:

$1=$ Strongly Disagree $(\mathrm{SD}), 2$ = Disagree (D), 3 = Neither agree nor disagree $(\mathrm{N}), 4$ = Agree (A), 5 = Strongly Agree $(\mathrm{SA})$ 


\section{Respondents' Views of Using Computer-based Assessment}

Using a five-point Likert Scale, where 1 indicated strongly disagree and 5 indicated strongly agree, respondents were asked to state their views to a series of statements that looked at different points of using CBA. An analysis of Table 3 reveals that most all mean statistics among 129 Year 1, 104 Year 2, and 55 Year 3 students ranged between 3.74 and 4.63 on five-point Likert Scale across nearly all points of using CBA. Additionally, standard deviations averaged about 0.90 for most points suggesting a large degree of agreement between Year 1, Year 2 and Year 3 students of using CBA in accounting modules (see, Marriott \& Lau, 2008; Marriott, 2009; Marriott \& Teoh, 2012a, 2012b; Potter \& Johnston, 2006). This reflects the fact that the majority ( $60 \%$ or more) of the three groups indicated agree or strongly agree. However, a small percentage of Year 1, Year 2 and Year 3 groups thought that all most points were disagreed or strongly disagreed for using CBA in accounting modules.

For example, the proportions of Year 1 students who agreed/strongly agreed for using CBA in accounting modules, knowing results immediately, support given before the CBA (92\%, $95 \%$ \& $89 \%$ respectively), were very similar to those of Year 2 and Year 3 students (89\%, $93 \% \& 82 \%$ and $76 \%, 82 \% \& 80 \%$ respectively). Therefore, the majority of Year 1 , Year 2 and Year 3 students $(67 \%, 65 \%$ \& 55\% respectively) preferred using CBA rather than paperand-pencil exams to assess their academic progress. Regarding the CBA questions' style/format, the vast majority of the three years cohorts preferred to answer multiple-choice, true/false and calculation questions, as seen in Table 3. Of-course, this is consistent with the findings of the existing accounting education literature which indicate that these questions' styles are suitable for different learning attitudes (see, Aisbitt \& Sangster, 2005; Marriot \& Lau, 2008; Einig, 2013). Moreover, the majority of Year 1, Year 2 and Year 3 students shared similar views the agreement of CBA to be phased and tested small areas of the 
syllabus $(74 \%, 75 \%$ \& $67 \%$ respectively), used many times through the semester $(77 \%, 72 \%$ $\& 70 \%$ respectively), and mixed approach of assessment, CBA and paper exam $(72 \%, 70 \% \&$ $76 \%$ respectively (see, Marriott, 2009). Interestingly, however, fewer than $13 \%$ of Year 1 , $12 \%$ of Year 2 and 11\% of Year 3 students agreed/strongly agreed that "if they do well in the CBA they would not work so hard for final exam". For the overall results, Table 3 below shows that the majority of students across the three years were agreed and most agreed with using CBA in accounting modules with overall 5-point means ranged between 3.94 and 4.60.

As apparent from Table 3, only on two points, namely prefer CBA as opposed to the paperand-pencil exam and answer multiple-choice questions, were the different views of three groups statistically significant. These differences are due to the percentage of respondents who disagreed/strongly disagreed, which were comprised of $3 \%$ \& $2 \%$ (for Year 1 ), $4 \%$ \& $11 \%$ (for Year 2) and 12\% \& 6\% (for Year 3) respectively. However, as seen in Table 3 below, the majority of Year $1(67 \%$ \& 87\%), Year $2(65 \%$ \& 73\%) and Year $3(55 \%$ \& 64\%) preferred CBA and multiple-choice questions. For the other related points to CBA, the asymptotic values (Asymp. Sig) are more than 0.05 in every instance. This means that the students' perceptions of using CBA are not affected by the students' year groups.

The respondents also expressed their favourable perceptions of CBA compared to paper-andpencil assessments (McDonald, 2002; Marriott, 2009; Marriott \& Teoh, 2012b; Potter \& Johnston, 2006). For example, see below some selected common quotes made by respondents:

"I like CBA as you can do it when you want and it gives you some reassurance going into the exam..." (21 yrs. UK Female Year 1 Acc)

"I prefer CBA which contains short questions or MCQs because they have always enabled me to learn more." (22 yrs. UK Male Year 1 Non-Acc) 
"Online numerical/multiple choice questions so I don't have to wait for results. Instant feedback with answers and explanation." (19 yrs. UK Female Year 2 Acc)

“Most prefer to CBA rather than paper tests." (23 yrs. Overseas Male Year 3 Acc)

Equally, an experienced 3-year overseas student support the above insights by asserting that:

"Computer-based test with a prompt feedback for the mid-term test is my preferable test, as it inspires us to revise the knowledge that we know and be prepared for the final exam." (24 yrs. Overseas Male Year 3 Non-Acc)

Thus, the above insights provide greater insights into the understanding of respondents' favourable perceptions of CBA, compared to paper-and-pencil exams (see, Clariana \& Wallace, 2002; McDonald, 2002). 
Table 3: Respondents' Views of Using Computer-based Assessment

\begin{tabular}{|c|c|c|c|c|c|c|c|c|c|c|c|c|c|c|c|c|c|c|c|}
\hline \multirow{3}{*}{ Statements } & \multicolumn{5}{|c|}{ Year 1 Group $(n=129)$} & \multicolumn{5}{|c|}{ Year 2 Group $(n=104)$} & \multicolumn{5}{|c|}{ Year 3 Group $(n=55)$} & \multicolumn{2}{|c|}{$\begin{array}{l}\text { Total Respondents } \\
\quad(n=288) \\
\text { Year 1, } 2 \& 3\end{array}$} & \multicolumn{2}{|c|}{$\begin{array}{c}\text { Kruskal-Wallis } \\
\text { Test }\end{array}$} \\
\hline & \multicolumn{3}{|c|}{ \% of Useable Responses } & \multirow[b]{2}{*}{$\begin{array}{c}\text { 5-Point } \\
\text { Mean }\end{array}$} & \multirow[b]{2}{*}{$\begin{array}{l}\text { Std. } \\
\text { Dev }\end{array}$} & \multicolumn{3}{|c|}{ \% of Useable Responses } & \multirow[b]{2}{*}{$\begin{array}{l}5- \\
\text { Point } \\
\text { Mean }\end{array}$} & \multirow[b]{2}{*}{$\begin{array}{l}\text { Std. } \\
\text { Dev }\end{array}$} & \multicolumn{3}{|c|}{ \% of Useable Responses } & \multirow[b]{2}{*}{$\begin{array}{l}5- \\
\text { Point } \\
\text { Mean }\end{array}$} & \multirow[b]{2}{*}{$\begin{array}{l}\text { Std. } \\
\text { Dev }\end{array}$} & \multirow[b]{2}{*}{$\begin{array}{l}\text { 5- } \\
\text { Point } \\
\text { Mean }\end{array}$} & \multirow[b]{2}{*}{$\begin{array}{l}\text { Std. } \\
\text { Dev }\end{array}$} & \multirow[b]{2}{*}{$\mathbf{X}^{2}$} & \multirow[b]{2}{*}{$\begin{array}{l}\text { Asymp } \\
\text {.Sig }\end{array}$} \\
\hline & $\begin{array}{l}\text { A/SA } \\
4-5\end{array}$ & $\begin{array}{l}\mathbf{N} \\
\mathbf{3}\end{array}$ & $\begin{array}{c}\mathrm{SD} / \mathrm{D} \\
1-2\end{array}$ & & & $\begin{array}{l}\mathrm{A} / \mathrm{SA} \\
\mathbf{4 - 5}\end{array}$ & $\begin{array}{l}\mathbf{N} \\
\mathbf{3}\end{array}$ & $\begin{array}{c}\mathrm{SD} / \mathrm{D} \\
1-2\end{array}$ & & & $\begin{array}{l}\mathrm{A} / \mathrm{A} \\
4-5\end{array}$ & $\begin{array}{l}\mathbf{N} \\
\mathbf{3}\end{array}$ & $\begin{array}{c}\mathrm{SD} / \mathrm{D} \\
1-2\end{array}$ & & & & & & \\
\hline $\begin{array}{l}\text { Q6. I am satisfied with the use of CBA } \\
\text { in the assessment of accounting } \\
\text { modules }\end{array}$ & 92 & 3 & 5 & 4.37 & 0.885 & 89 & 9 & 2 & 4.44 & 0.890 & 76 & 14 & 10 & 4.13 & 1.106 & 4.35 & 0.936 & 3.191 & 0.203 \\
\hline $\begin{array}{l}\text { Q7. I like knowing my result from } \\
\text { CBA immediately }\end{array}$ & 95 & 3 & 2 & 4.63 & 0.761 & 93 & 7 & 0 & 4.63 & 0.753 & 82 & 14 & 4 & 4.46 & 0.940 & 4.60 & 0.795 & 0.882 & 0.643 \\
\hline $\begin{array}{l}\text { Q8. I prefer sitting a CBA as opposed } \\
\text { to paper-and-pencil assessment }\end{array}$ & 67 & 30 & 3 & 4.15 & 1.0833 & 65 & 31 & 4 & 4.14 & 1.089 & 55 & 33 & 12 & 3.74 & 1.060 & 4.11 & 1.110 & 6.674 & 0.036 \\
\hline Q9. I felt fully prepared to sit the test & 73 & 22 & 5 & 4.11 & 1.033 & 77 & 18 & 5 & 4.14 & 0.976 & 59 & 39 & 2 & 3.95 & 0.970 & 4.11 & 0.999 & 2.215 & 0.330 \\
\hline $\begin{array}{l}\text { Q10. I am happy with the support } \\
\text { given before the test (e.g. reminders, } \\
\text { CBA instructions, and mock CBA) }\end{array}$ & 89 & 9 & 2 & 4.51 & 0.894 & 82 & 13 & 5 & 4.35 & 0.993 & 80 & 10 & 10 & 4.22 & 1.150 & 4.40 & 0.986 & 3.137 & 0.208 \\
\hline $\begin{array}{l}\text { Q11. I prefer to answer multiple } \\
\text { choice questions }\end{array}$ & 87 & 11 & 2 & 4.54 & 0.866 & 73 & 16 & 11 & 4.18 & 1.130 & 64 & 30 & 6 & 4.11 & 1.083 & 4.33 & 1.025 & 9.395 & 0.009 \\
\hline $\begin{array}{l}\text { Q12. I prefer to answer true/false } \\
\text { questions }\end{array}$ & 69 & 23 & 8 & 4.14 & 1.123 & 63 & 27 & 10 & 4.10 & 1.170 & 52 & 26 & 22 & 3.73 & 1.367 & 4.03 & 1.195 & 3.608 & 0.165 \\
\hline $\begin{array}{l}\text { Q13. I prefer to answer calculation } \\
\text { questions }\end{array}$ & 67 & 23 & 10 & 4.02 & 1.170 & 58 & 29 & 13 & 3.87 & 1.200 & 58 & 34 & 8 & 3.86 & 1.044 & 3.93 & 1.156 & 2.325 & 0.313 \\
\hline $\begin{array}{l}\text { Q14. CBA can add value to my } \\
\text { learning }\end{array}$ & 76 & 21 & 3 & 4.25 & 0.992 & 67 & 27 & 6 & 4.14 & 1.111 & 63 & 33 & 4 & 4.12 & 1.054 & 4.17 & 1.043 & 2.400 & 0.301 \\
\hline
\end{tabular}


Table 3: Respondents' Views of Using Computer-based Assessment

(Cont-)

\begin{tabular}{|c|c|c|c|c|c|c|c|c|c|c|c|c|c|c|c|c|c|c|c|}
\hline \multirow{3}{*}{ Statements } & \multicolumn{5}{|c|}{ Year 1 Group $(n=129)$} & \multicolumn{5}{|c|}{ Year 2 Group $(n=104)$} & \multicolumn{5}{|c|}{ Year 3 Group $(n=55)$} & \multicolumn{2}{|c|}{$\begin{array}{c}\begin{array}{c}\text { Total } \\
\text { Respondents } \\
(\mathbf{n}=\mathbf{2 8 8})\end{array} \\
\text { Year 1, } 2 \& 3\end{array}$} & \multicolumn{2}{|c|}{$\begin{array}{c}\text { Kruskal-Wallis } \\
\text { Test }\end{array}$} \\
\hline & \multicolumn{3}{|c|}{ \% of Useable Responses } & \multirow[b]{2}{*}{$\begin{array}{l}5- \\
\text { Point } \\
\text { Mean }\end{array}$} & \multirow[b]{2}{*}{$\begin{array}{l}\text { Std. } \\
\text { Dev }\end{array}$} & \multicolumn{3}{|c|}{ \% of Useable Responses } & \multirow[b]{2}{*}{$\begin{array}{l}5- \\
\text { Point } \\
\text { Mean }\end{array}$} & \multirow[b]{2}{*}{$\begin{array}{l}\text { Std. } \\
\text { Dev }\end{array}$} & \multicolumn{3}{|c|}{ \% of Useable Responses } & \multirow[b]{2}{*}{$\begin{array}{l}5- \\
\text { Point } \\
\text { Mean }\end{array}$} & \multirow[b]{2}{*}{$\begin{array}{l}\text { Std. } \\
\text { Dev }\end{array}$} & \multirow[b]{2}{*}{$\begin{array}{l}5- \\
\text { Point } \\
\text { Mean }\end{array}$} & \multirow[b]{2}{*}{$\begin{array}{l}\text { Std. } \\
\text { Dev }\end{array}$} & \multirow[b]{2}{*}{$\mathbf{X}^{2}$} & \multirow[b]{2}{*}{$\begin{array}{l}\text { Asymp. } \\
\text { Sig }\end{array}$} \\
\hline & $\begin{array}{l}\text { A/SA } \\
4-5\end{array}$ & $\begin{array}{l}\mathbf{N} \\
\mathbf{3}\end{array}$ & $\begin{array}{c}\mathrm{SD} / \mathrm{D} \\
1-2\end{array}$ & & & $\begin{array}{l}\text { A/SA } \\
4-5\end{array}$ & $\begin{array}{l}\mathbf{N} \\
\mathbf{3}\end{array}$ & $\begin{array}{r}\mathrm{SD} / \mathrm{D} \\
1-2\end{array}$ & & & $\begin{array}{r}\text { A/SA } \\
4-5\end{array}$ & $\begin{array}{l}\mathbf{N} \\
\mathbf{3}\end{array}$ & $\begin{array}{c}\mathrm{SD} / \mathrm{D} \\
1-2\end{array}$ & & & & & & \\
\hline $\begin{array}{l}\text { Q15. I prefer CBA to be phased and } \\
\text { test small areas of the syllabus } \\
\text { rather than one test that covers } \\
\text { many topics }\end{array}$ & 74 & 20 & 6 & 4.27 & 1.110 & 75 & 17 & 8 & 4.26 & 1.141 & 67 & 27 & 6 & 4.10 & 1.110 & 4.23 & 1.111 & 1.379 & 0.502 \\
\hline $\begin{array}{l}\text { Q16. Phased CBA (i.e. a number of } \\
\text { smaller assessments through the } \\
\text { semester) would improve my } \\
\text { learning }\end{array}$ & 77 & 20 & 3 & 4.30 & 1.010 & 72 & 22 & 6 & 4.30 & 1.114 & 70 & 22 & 8 & 4.00 & 1.018 & 4.25 & 1.052 & 4.215 & 0.122 \\
\hline $\begin{array}{l}\text { Q17. Phased CBA would encourage } \\
\text { me to work consistently throughout } \\
\text { the semester }\end{array}$ & 84 & 14 & 2 & 4.35 & 0.924 & 79 & 19 & 2 & 4.42 & 1.002 & 86 & 14 & 0 & 4.34 & 0.844 & 4.38 & 0.936 & 0.592 & 0.744 \\
\hline $\begin{array}{l}\text { Q18. I am happy with a mixed } \\
\text { approach of assessment (i.e. CBA } \\
\text { and paper-and-pencil exam at the } \\
\text { end of the semester) }\end{array}$ & 72 & 18 & 10 & 4.01 & 1.110 & 70 & 22 & 8 & 4.21 & 1.146 & 76 & 18 & 6 & 4.10 & 1.016 & 4.10 & 1.110 & 2.004 & 0.367 \\
\hline $\begin{array}{l}\text { Q19. If I do badly in the CBA it } \\
\text { would motivate me to work harder } \\
\text { for the final exam }\end{array}$ & 74 & 18 & 8 & 4.15 & 1.140 & 75 & 18 & 7 & 4.30 & 1.114 & 74 & 16 & 10 & 4.04 & 1.110 & 4.18 & 1.120 & 2.151 & 0.341 \\
\hline $\begin{array}{l}\text { Q20. If I do well in the CBA I would } \\
\text { not work so hard for the final exam }\end{array}$ & 12 & 17 & 71 & 2.55 & 1.540 & 11 & 19 & 70 & 2.71 & 1.687 & 10 & 18 & 72 & 2.42 & 1.500 & 2.58 & 1.584 & 0.980 & 0.613 \\
\hline
\end{tabular}




\section{Respondents' Views of Usefulness and Occurrence of CBA}

In this section of the online survey, respondents were asked to state the best choice for the usefulness and occurrence of CBA in accounting modules. A list of suggested options was developed mainly based on previous studies. Analysis of students' responses is provided in Table 4 below. Half of the respondents (50\%) preferred CBA to be summative only compared to $27 \%$ preferred CBA to be both formative and summative assessment. It is also noted that the majority of Year $1 \&$ Year 3 students (54\% \& 49\% respectively) preferred CBA as a summative rather than formative assessment compared to Year 2 students (46\%). In a very similar vein, the majority of Year 1 , Year $2 \&$ Year 3 students preferred that CBA should be used on both numerical and non-numerical accounting modules $(63 \%, 51 \%$ \& 53\% respectively) with 58\% of overall agreement (Marriott \& Teoh, 2012a, 2012b; Potter \& Johnston, 2006).

With regard to the appropriateness of CBA to have complex questions, it is noted that Year 2 \& Year 3 were more agreed (43\% \& 53\% respectively) than Year 1 students $(37 \%)$. While $36 \%$ of Year 1, 28\% of Year 2 and $27 \%$ of Year 3 students were neither agreed nor disagreed with the CBA to include complex questions. In contrast to $35 \%$ of Year 2 students, $48 \%$ of Year 1 and $45 \%$ of Year 3 preferred that CBAs should take place at least once a semester in accounting modules, with $43 \%$ agreement of the total respondents. However, about $37 \%$ of the total respondents thought that these CBAs should take place at least once a month in accounting modules. Finally, for the proper length of CBA, there was a disagreement between the three groups about the right length of time for each CBA. However, there is a general belief among the three groups that the duration of a CBA should be between 31 and 60 minutes (see, Loewenberger \& Bull, 2003; O'Connell et al., 2010). 
As shown in Table 4 below, the ideal length of time for a CBA indicated statistically significant differences in responses between the three groups Year 1, Year $2 \&$ Year 3. CBA time between 15 and 30 minutes received higher ratings of the agreement by Year $2 \&$ Year 3 students (23\% \& 27\% respectively) than Year 1 students (7\%). 53\% of Year 1 and $49 \%$ of Year 3 students preferred the CBA length of to be 31 to 60 minutes compared to $38 \%$ of Year 2 students. While $28 \%$ of Year 1 and $21 \%$ of Year 2 students preferred the CBA time to be between 60 and 90 minutes compared to just $15 \%$ of Year 3 students. These differences between the three groups could be attributed to differences in background and experience of each group and/or the personal preferences of the ideal length of CBA (Loewenberger \& Bull, 2003). For the other related points to the usefulness and occurrence of CBA, the asymptotic values (Asymp. Sig) are more than 0.05 in every instance. This means that the students' perceptions of the usefulness and/or occurrence of CBA are not affected by the students' year groups. 
Table 4: Respondents' Views of Usefulness and Occurrence of CBA

\begin{tabular}{|c|c|c|c|c|c|c|c|c|c|c|}
\hline \multirow[t]{2}{*}{ Statements } & \multicolumn{2}{|c|}{ Year 1 Group $(n=129)$} & \multicolumn{2}{|c|}{ Year 2 Group $(n=104)$} & \multicolumn{2}{|c|}{ Year 3 Group $(n=55)$} & \multicolumn{2}{|c|}{ Total Respondents $(n=288)$} & \multicolumn{2}{|c|}{ Kruskal-Wallis Test } \\
\hline & Frequency & $\%$ & Frequency & $\%$ & Frequency & $\%$ & Frequency & $\%$ & $\mathrm{X}^{2}$ & $\begin{array}{c}\text { Asymp. } \\
\text { Sig }\end{array}$ \\
\hline \multicolumn{9}{|l|}{ Q21. I prefer CBA to be: } & \multirow{6}{*}{1.578} & \multirow{6}{*}{0.454} \\
\hline a- Formative only & 4 & 3 & 3 & 3 & 2 & 4 & 9 & 3 & & \\
\hline b- Summative only & 67 & 54 & 48 & 46 & 27 & 49 & 142 & 50 & & \\
\hline c- Combination of both & 36 & 29 & 27 & 26 & 16 & 29 & 79 & 27 & & \\
\hline d- Not preference & 7 & 2 & 8 & 8 & 5 & 9 & 20 & 7 & & \\
\hline e- No answer & 15 & 12 & 18 & 17 & 5 & 9 & 38 & 13 & & \\
\hline \multicolumn{9}{|l|}{ Q22. In my opinion, CBA should: } & \multirow{6}{*}{3.207} & \multirow{6}{*}{0.201} \\
\hline a- Be used on numerical modules & 24 & 19 & 25 & 24 & 15 & 27 & 64 & 22 & & \\
\hline b- Be used on non-numerical modules & 6 & 5 & 6 & 6 & 6 & 11 & 18 & 6 & & \\
\hline c- Both & 83 & 63 & $\mathbf{5 3}$ & 51 & 29 & 53 & 165 & 58 & & \\
\hline d- Not be used at all & 1 & 1 & 2 & 2 & $\mathbf{0}$ & $\mathbf{0}$ & 3 & 1 & & \\
\hline e- No answer & 15 & 12 & 18 & 17 & 5 & 9 & 38 & 13 & & \\
\hline \multicolumn{9}{|c|}{ Q23. Complex questions are not appropriate for CBAs: } & \multirow{5}{*}{2.804} & \multirow{5}{*}{0.246} \\
\hline a- Agree/Strongly Agree & 48 & 37 & 45 & 43 & 29 & 53 & 122 & 42 & & \\
\hline b- Neither Agree nor Disagree & 47 & 36 & 29 & 28 & 15 & 27 & 91 & 32 & & \\
\hline c- Disagree/Strongly Disagree & 19 & 15 & 12 & 12 & 6 & 11 & 37 & 13 & & \\
\hline d- Not applicable & 15 & 12 & 18 & 17 & 5 & 9 & 38 & 13 & & \\
\hline
\end{tabular}


Table 4: Respondents' Views of Usefulness and Occurrence of CBA

(Cont-)

\begin{tabular}{|c|c|c|c|c|c|c|c|c|c|c|}
\hline \multirow[t]{2}{*}{ Statements } & \multicolumn{2}{|c|}{ Year 1 Group $(n=129)$} & \multicolumn{2}{|c|}{ Year 2 Group $(n=104)$} & \multicolumn{2}{|c|}{ Year 3 Group $(n=55)$} & \multicolumn{2}{|c|}{ Total Respondents $(\mathrm{n}=\mathbf{2 8 8})$} & \multicolumn{2}{|c|}{ Kruskal-Wallis Test } \\
\hline & Frequency & $\%$ & Frequency & $\%$ & Frequency & $\%$ & Frequency & $\%$ & $\mathbf{X}^{2}$ & $\begin{array}{c}\text { Asymp. } \\
\text { Sig }\end{array}$ \\
\hline \multicolumn{9}{|c|}{ Q24. Where CBAs are used on modules, they should take place at least: } & \multirow{6}{*}{1.034} & \multirow{6}{*}{0.596} \\
\hline a- Once a week & 4 & 3 & 11 & 11 & 3 & 6 & 18 & 6 & & \\
\hline b- Once a month & 46 & 35 & 38 & 36 & 21 & 38 & 105 & 37 & & \\
\hline c- Once a semester & 62 & 48 & 36 & 35 & 25 & 45 & 123 & 43 & & \\
\hline d- Once a year & 2 & 2 & 1 & 1 & $\mathbf{0}$ & $\mathbf{0}$ & 3 & 1 & & \\
\hline e- No answer & 15 & 12 & 18 & 17 & 6 & 11 & 39 & 13 & & \\
\hline \multicolumn{9}{|c|}{ Q25. The ideal length of time for a CBA is: } & \multirow{6}{*}{8.585} & \multirow{6}{*}{0.014} \\
\hline a- 15-30 minutes & 9 & 7 & 24 & 23 & 15 & 27 & 48 & 17 & & \\
\hline b- 31- 60 minutes & 68 & 53 & 40 & 38 & 27 & 49 & 135 & 47 & & \\
\hline c- 61- 75 minutes & 29 & 22 & 19 & 18 & 6 & 11 & 54 & 19 & & \\
\hline d- 76- 90 minutes & 8 & 6 & 3 & 3 & 2 & 4 & 13 & 4 & & \\
\hline e- No answer & 15 & 12 & 18 & 17 & 5 & 9 & 38 & 13 & & \\
\hline
\end{tabular}




\section{Respondents' Views of Using Computer-based Feedback}

Section 5 in the online survey asked students to rate 8 specific statements on the online feedback on a scale ranging from 1 (strongly disagree) to 5 (strongly agree) in relation to their own perception of the given feedback in Accounting modules. While the final statement asked the student to state the most prompt feedback they received from other module(s).

An analysis of Table 5 reveals that most all mean statistics among the respondents ranged between 3.84 and 4.50 on five-point Likert Scale across nearly all aspects of CBF. For example, the proportions of Year 1 students who agreed/strongly agreed for prompt release of $\mathrm{CBF}$, given $\mathrm{CBF}$, value of given $\mathrm{CBF}$ and style of $\mathrm{CBF}$ compared to handwritten feedback $(85 \%, 86 \%, 87 \% \& 89 \%$ respectively), were very similar to those of Year $2 \&$ Year $3(87 \%$, $82 \%, 74 \% \& 85 \%$ and $84 \%, 70 \%, 72 \% \& 76 \%$ respectively). Table 5 shows that at least $50 \%$ of students prefer "receiving general feedback to the class as whole" explaining the common mistakes and how to improve future performance. Students' scores for a statement relating to "Feedback helps Lecturers/Tutors understand where students are having difficulties" were high (83\% agreed/disagreed). This suggests that students would appreciate the use of feedback as promoting a personalised dialogue with their teachers (see, Carless, 2006; Marriott \& Teoh, 2012a, 2012b; O’Connell et al., 2010).

As seen in Table 5 below, the figures show the distribution of responses to the most prompt feedback they received on their assessments. Overall, these figures show a strong preference by respondents for quick feedback. For example, 27\% of Year 1, 35\% of Year 2 and 22\% of Year 3 received feedback on their assessments immediately after submission. However, it was surprising that some did not seem to mind waiting over two weeks to receive feedback on their assessments particularly for $44 \%$ of Year 3 compared to $22 \%$ of Year $1 \&$ Year 2. This result supports the previous education literature (e.g. O'Connell et al. 2010). Perhaps 
this reflects academic policy at some departments where two week-period is stated as the time suggested under assessment guidelines to provide a comprehensive feedback reports on their students' assessments, or due to the availability of second markers and time required by admin staff to scan and upload feedback forms to VLE, etc.

As is evident from Table 5 only on one point, namely " $C B F$ is useful to revise from and prepare for final exam", were the different views of the three groups statistically significant. These differences are due to the percentage of respondents who agreed/strongly agreed, which were comprised of $89 \%$ (for Year 1), 71\% (for Year 2) 50\% (for Year 3). However, as seen in Table 5, the vast minority of Year $1(1 \%)$ and Year $2(7 \%)$ disagreed or strongly disagreed that $\mathrm{CBF}$ is useful to revise and prepare for the final exam, compared to $20 \%$ of Year 3 students. For the other related points to CBF, the asymptotic values (Asymp. Sig) are more than 0.05 in every instance. This means that the students' views of using CBF in accounting modules are not affected by the students' year groups and their academic experience and background.

The respondents also expressed their favourable perceptions of $\mathrm{CBF}$ compared to late and handwritten feedback on paper-and-pencil assessments (Marriott, 2009; Marriott \& Teoh, 2012b; Potter \& Johnston, 2006). For example, see below some selected common views made by respondents:

"...In terms of feedback, I liked the timely and prompt feedback as you get it straight away." (21 yrs. UK Female Year 1 Acc)

"Prompt and detailed feedback-feedforward is desirable because it helps me to understand correct answers to my mistakes." (22 yrs. UK Male Year 1 Non-Acc)

"I don't have to wait for the marks, taking CBA is combined with prompt online feedback with answers and explanation." (19 yrs. UK Male Year 2 Acc)

"...this type of CBF rather than paper-and-pencil assessments. No need to wait for a few weeks and get the result from the school office, this is more convenient for me." (23 yrs. Overseas Female Year 3 Acc) 
Accordingly, the above quotes offer better insights into the understanding of respondents' positive perceptions of prompt and detailed $\mathrm{CBF}$, compared to handwritten ones (see, Clariana \& Wallace, 2002; McDonald, 2002). 
Table 5: Respondents' Views of using Computer-based Feedback

\begin{tabular}{|c|c|c|c|c|c|c|c|c|c|c|c|c|c|c|c|c|c|c|c|}
\hline \multirow{3}{*}{ Statements } & \multicolumn{5}{|c|}{ Year 1 Group $(n=129)$} & \multicolumn{5}{|c|}{ Year $2 \operatorname{Group}(n=104)$} & \multicolumn{5}{|c|}{ Year 3 Group $(n=55)$} & \multicolumn{2}{|c|}{$\begin{array}{c}\begin{array}{c}\text { Total } \\
\text { Respondents } \\
(\mathrm{n}=\mathbf{2 8 8})\end{array} \\
\text { Year 1, } 2 \& 3\end{array}$} & \multicolumn{2}{|c|}{$\begin{array}{l}\text { Kruskal-Wallis } \\
\text { Test }\end{array}$} \\
\hline & \multicolumn{3}{|c|}{ \% of Respondents } & \multirow[b]{2}{*}{$\begin{array}{l}5- \\
\text { Point } \\
\text { Mean }\end{array}$} & \multirow[b]{2}{*}{$\begin{array}{l}\text { St. } \\
\text { Dev }\end{array}$} & \multicolumn{3}{|c|}{$\%$ of Respondents } & \multirow[b]{2}{*}{$\begin{array}{l}\text { 5- } \\
\text { Point } \\
\text { Mean }\end{array}$} & \multirow[b]{2}{*}{$\begin{array}{l}\text { Std. } \\
\text { Dev }\end{array}$} & \multicolumn{3}{|c|}{ \% of Respondents } & \multirow[b]{2}{*}{$\begin{array}{l}5- \\
\text { Point } \\
\text { Mean }\end{array}$} & \multirow[b]{2}{*}{$\begin{array}{l}\text { Std. } \\
\text { Dev }\end{array}$} & \multirow[b]{2}{*}{$\begin{array}{l}5- \\
\text { Point } \\
\text { Mean }\end{array}$} & \multirow[b]{2}{*}{$\begin{array}{l}\text { Std. } \\
\text { Dev }\end{array}$} & \multirow[b]{2}{*}{$\mathbf{X}^{2}$} & \multirow[b]{2}{*}{$\begin{array}{l}\text { Asymp. } \\
\text { Sig }\end{array}$} \\
\hline & $\begin{array}{l}\mathrm{A} / \mathrm{SA} \\
4-5\end{array}$ & $\begin{array}{l}\mathbf{N} \\
\mathbf{3}\end{array}$ & $\begin{array}{c}\text { SD/D } \\
1-2\end{array}$ & & & $\begin{array}{l}\mathrm{A} / \mathrm{SA} \\
4-5\end{array}$ & $\begin{array}{l}\mathbf{N} \\
\mathbf{3}\end{array}$ & $\begin{array}{r}\text { SD/D } \\
1-2\end{array}$ & & & $\begin{array}{r}\text { A/SA } \\
4-5\end{array}$ & $\begin{array}{l}\mathbf{N} \\
\mathbf{3}\end{array}$ & $\begin{array}{l}\text { SD/D } \\
1-2\end{array}$ & & & & & & \\
\hline $\begin{array}{l}\text { Q26. I find the prompt release of } \\
\text { CBF from CBA valuable }\end{array}$ & 85 & 15 & $\mathbf{0}$ & 4.46 & 0.875 & 87 & 12 & 1 & 4.55 & 0.923 & 84 & 16 & $\mathbf{0}$ & 4.36 & 0.868 & 4.50 & 0.891 & 1.672 & 0.433 \\
\hline $\begin{array}{l}\text { Q27. I am satisfied with the CBF } \\
\text { given }\end{array}$ & 86 & 12 & 2 & 4.41 & 0.898 & 82 & 11 & 7 & 4.42 & 1.105 & 70 & 22 & 8 & 4.10 & 1.160 & 4.40 & 1.030 & 3.244 & 0.198 \\
\hline $\begin{array}{l}\text { Q28. CBF helps me to understand } \\
\text { where I personally went wrong }\end{array}$ & 87 & 12 & 1 & 4.40 & 0.896 & 74 & 18 & 8 & 4.28 & 1.153 & 72 & 22 & 6 & 4.15 & 1.110 & 4.31 & 1.034 & 1.927 & 0.382 \\
\hline $\begin{array}{l}\text { Q29. CBF removes the problem of } \\
\text { illegible handwriting }\end{array}$ & 89 & 10 & 1 & 4.47 & 0.876 & 85 & 14 & 1 & 4.50 & 0.955 & 76 & 22 & 2 & 4.24 & 0.962 & 4.43 & 0.924 & 3.077 & 0.215 \\
\hline $\begin{array}{l}\text { Q30. CBF is useful to revise from } \\
\text { and prepare for the final exam }\end{array}$ & 89 & 10 & 1 & 4.41 & 0.853 & 71 & 22 & 7 & 4.23 & 1.176 & 50 & 30 & 20 & 3.64 & 1.253 & 4.20 & 1.104 & 17.741 & 0.000 \\
\hline $\begin{array}{l}\text { Q31. I like general feedback to the } \\
\text { class as a whole }\end{array}$ & 58 & 29 & 13 & 3.86 & 1.223 & 49 & 36 & 15 & 3.86 & 1.295 & 49 & 28 & 23 & 3.75 & 1.336 & 3.84 & 1.300 & 0.524 & 0.770 \\
\hline $\begin{array}{l}\text { Q32. } \quad \text { Feedback } \\
\text { lecturers/Tutors understand where I } \\
\text { am having difficulties }\end{array}$ & 83 & 16 & 1 & 4.32 & 0.884 & 84 & 12 & 4 & 4.40 & 1.031 & 83 & 11 & 6 & 4.16 & 1.032 & 4.32 & 0.967 & 4.043 & 0.132 \\
\hline
\end{tabular}


Table 5: Respondents' Views of using Computer-based Feedback

(Cont-)

\begin{tabular}{|c|c|c|c|c|c|c|c|c|c|c|}
\hline \multirow[t]{2}{*}{ Statements } & \multicolumn{2}{|c|}{ Year 1 Group $(n=129)$} & \multicolumn{2}{|c|}{ Year 2 Group $(n=104)$} & \multicolumn{2}{|c|}{ Year 3 Group $(n=55)$} & \multicolumn{2}{|c|}{ Total Respondents $(\mathrm{n}=\mathbf{2 8 8})$} & \multicolumn{2}{|c|}{ Kruskal-Wallis Test } \\
\hline & Frequency & $\%$ & Frequency & $\%$ & Frequency & $\%$ & Frequency & $\%$ & $\mathrm{X}^{2}$ & $\begin{array}{c}\text { Asymp. } \\
\text { Sig }\end{array}$ \\
\hline \multicolumn{9}{|c|}{ Q33. What is the most prompt feedback you have received so far from any OTHER module(s) assessment(s)? } & \multirow{7}{*}{2.099} & \multirow{7}{*}{0.350} \\
\hline a- On submission & 34 & 27 & 36 & 35 & 12 & 22 & 82 & 28 & & \\
\hline b- Within one day & 12 & 9 & 5 & 5 & $\mathbf{0}$ & $\mathbf{0}$ & 17 & 6 & & \\
\hline c- Within two days & 8 & 6 & 2 & 2 & 1 & 2 & 11 & 4 & & \\
\hline d- Within one week & 30 & 24 & 19 & 18 & 11 & 20 & 60 & 21 & & \\
\hline e- More than two weeks & 29 & 22 & 23 & 22 & 24 & 44 & 76 & 26 & & \\
\hline f- No answer & 16 & 12 & 19 & 18 & 7 & 12 & 42 & 15 & & \\
\hline
\end{tabular}




\section{Respondents' Comments on $C B F$ and $C B A$}

Finally, the last section of the survey gave students a free space to briefly describe their own experience of CBA and what makes it effective, most desirable forms of effective feedback and other comments on CBAF.

For the experience of CBA and what makes it effective below are some selected common quotes made by students:

"...my experience provided me with an insight into one of the assessment processes at university and it was affective due to its ability to check my knowledge gained from lecturers and seminars in my own time." (20 yrs. UK Male Year 1 Acc)

"...the online test enables me to complete an exam within the comfort of my own house in my own time and I feel much less pressure. I also am able to take breaks if needed" (21 yrs. Overseas Female Year 2 Non-Acc)

"...the online assessment was good because it had a mix of true/false questions and calculation questions, so people can still gain marks from a wider choice, which makes it effective. I prefer the online assessment instead of paper assignments" (23 yrs. UK Female, Year 3 Acc)

For the effective form of feedback, participants made some significant quotes below:

“...instantaneous feedback, that is personalised (i.e. face-to-face discussion with my tutor" (19 yrs. UK Male, Year 1 Acc)

"...effective feedback means feedback that tells me I am wrong and why. It helps me to obtain the correct answer and then another example showing me how to complete the question, etc." (20 yrs. Overseas Female Year 2 Acc)

"...I prefer computerised feedback as it is instant feedback and it allows me to correct my thoughts while they are still fresh in my mind" (23 yrs. Overseas Male Year 3 Non-Acc)

While the more remarkable and mutual general comments on CBAF are:

"...I do believe that online assessment and feedback are highly useful for both ourselves and also for lecturers as they aid in reinforcing our knowledge of concepts, highlights the main areas of weakness that we are able to rectify. Personally, I would prefer weekly online tests which do not count towards the end assessment mark" (19 yrs. Overseas Male Year 1 Acc) 
“...the online assessments should be given to all accounting modules because they keep us active, to read and understand rather revising at the end of the semester which is not enough for exam preparation. The online feedback is good because we are given the answer rather than just showing us what we failed with no corrections for it" (20 yrs. UK Male Year 2 Acc)

"...online tests should be used across more modules, paper class tests are often disorganised and never feels like you have adequate time to complete them to the best of your ability. Online tests make you feel more relaxed, give practice in calculation and you always have time to reread and check your answers" (23 yrs. Overseas Female Year 3 Acc)

\section{Conclusions, Implications and Future Action Research}

The accounting education literature demonstrates that assessment and feedback play an important role in the T\&L process in HE (Einig, 2013; Jebeile \& Abeysekera, 2010; Marriott, 2009; O'Connell et al., 2010). In the one hand, for enhancing the efficiency of assessment, students need to fully understand the assessment criteria in terms of timing of assessment, assessment topic(s), and the assessment type (e.g. mid-term test, essay, assignment, online- or paper-and-pencil assessment), then they will be able to plan their study timetable in preparation for such assessment (Gibbs \& Simpson, 2005; Marriott, 2009). Thus, the clarity of the timing of assessments and their requirements and the introduction of summative and formative innovative CBA gave the digital natives (i.e. students) the ability to allocate their effort consistently over their modules of study (Evans, 2013; Gibbs \& Simpson, 2005; Massoudi et al., 2017). Additionally, timely and detailed feedback-feedforward reports should provide students with information that can monitor academic progress, diagnose and remedy weaknesses, promote their learning and improve their future performance (see, Litherland et al., 2013; Marriott \& Lau, 2008; Race, 2005; Simin \& Heidari, 2013; Timmis et al., 2016). On the other hand, for the teaching staff assessing students' progress and highlighting, at an early stage, those students were facing difficulties in understanding certain topic(s) enabled them to provide timely and suitable support where needed. This will 
lead to enhancing their motivation and engagements with the subject and filling the attainment gap.

Lastly, the accounting professional bodies such as ACCA and CIMA outlined the benefits of their on-demand CBA to paper-and-pencil test to their members (Al-Htaybat et al., 2018). For example, ACCA has offered CBA for the Foundation level awards since 1998 (Aisbitt \& Sangster, 2005; Rodrigues et al., 2018). The success of this step led to an increased number of ACCA papers being tested using CBA and this therefore, provides the next step in the move towards ACCA's vision to deliver all exam papers via CBA. Similarly, CIMA is working in partnership with Pearson VUE, which have over 20 years of experience in designing and offering CBA and already use CBA for the CIMA Certificate in Business Accounting exams. Regarding ACCA and CIMA CBAs, students who take their exams via CBA reported high level of satisfaction. The ACCA students, for example, stated that taking $\mathrm{CBA}$ is more flexible and not being restricted to a fixed exam schedule, taking resit much sooner, and instant results are provided. Accordingly, accounting departments should widely adopt such a very novel CBAF for assessing their accounting students. By doing so, they can ensure that they reduce the attainment gap and prepare their students for future computerised accounting career and professional accounting development as well. To sum, to maintain our accounting profession, we need to a computerised accountant who is able to deal with the high speed and mobility of corporate reporting environment, provide a reliable and accurate information in a very dynamic business environment.

\section{Key Findings}

This research assessed the students' perceptions of the use of CBAF in the T\&L process. In the digital age, paper-and-pencil assessments and handwritten feedback are not the ideal learning approach for "the current digital natives and "the teaching beyond the classroom environment". Reviewing the literature documented the usefulness of using IT in the T\&L 
environment to both lecturers and students compared to paper-and-pencil assessment and feedback practices. This study aimed to answer the following research question: How do students assess the use of CBA and/or CBF in T\&L accounting modules?

To answer this question, an online survey was used. This online survey was developed and used for undergraduate students at the management school of a British university who are assessed by CBAF. A student online survey gauged participants' CBAF perception and experience, $46 \%$ of participants (Year $2 \&$ Year 3) were users of CBAF, while 54\% of Year 1 did not use CBAF before. Further, the findings supported the proposition that CBAF can definitely provide an effective supernumerary assessment and feedback approach for HE undergraduate accounting students who are indeed "Digital Natives". These results are consistent with previous relevant education literature's findings (e.g. Aisbitt \& Sangster, 2005; Einig, 2013; Jebeile \& Abeysekera, 2010; Kirkwood \& Price, 2005; Marriott, 2009; Marriott \& Teoh, 2012a; O’Connell et al., 2010; Potter \& Johnston, 2006).

\section{Implications for Future Use of CBAF in T\&L in HE Environment}

Assessment is the way toward measuring students' academic progress, while feedbackfeedforward report comments on their academic progress and give them a guidance to enhance their strengths and correct their mistakes (Carless, 2006; Marriott \& Teoh, 2012b). Furthermore, recent NSSs state that students raised their concerns about the effectiveness of both assessment and feedback approach used to evaluate their performance. Responding to these concerns, many universities have presented inventive types of assessment and feedback. One of these creative practices, the utilization of CBAF (see, Aisbitt \& Sangster, 2005; Clariana \& Wallace, 2002; Hooligan et al., 2006; Evans, 2013; Jebeile \& Abeysekera, 2010; Thelwall, 2000). Accordingly, the results of this AR study make some recommendations to the other colleagues in HEIs to enhance the efficiency of the current CBAF practices, in turn. 


\section{A- For enhancing the efficiency of current practice of CBA:}

1. Delivering complete description of CBA structure and questions

2. Delivering a variety of questions' styles (e.g. MCQs, matching, short answers, calculations, True/False)

3. Providing mock CBAs

4. Asking students to check the reliability of the internet and their computers before answering their CBAs

5. Improving the User Interface Elements of the CBA

6. Setting proper content and duration of $\mathrm{CBA}$

\section{B- For enhancing the efficiency of current practice of CBF:}

1. Delivering diverse forms of feedback including typed, personal and verbal feedback

2. Delivering instant feedback (i.e. on submission or with the latest of two weeks from submission)

3. Utilising VLE features such as: grademark, screencast and emails to provide instant feedback

4. Delivering detailed feedback-feedforward on mistakes with a guidance to correct them and references to be reviewed for future assessments/exams

5. Delivering training workshops on how to use technology in the T\&L process to both students and teaching staff to solve the computer familiarities and anxiety problems

\section{Future Action Research}

This AR study has provided an insight into the accounting students' preferred methods of assessment and feedback and how CBA and/or CBF can have a positive impact on students' engagement in the T\&L environment. The results indicate that there is a general consensus among students about the importance of CBA and/or CBF as an effective tool for assessing the academic performance of the digital students in the digital age. Therefore, it could be argued considerable emphasis and research should be placed on students as co-partners and active agents with their tutors in the assessment and feedback process. Therefore, future research could collect further evidence from students from other disciplines that would add to the $\mathrm{CBA}$ and $\mathrm{CBF}$ debate and would provide evidence to establish the external validity of this 
study results and to conduct focus groups, lab experiments, and interviews with students to investigate the benefits and challenges of using CBAF. Likewise, conducting focus groups and individual interviews with staff is needed to investigate the reasons for (not)adopting technology in T\&L modules and the potential of technology to transform the student learning experience, advantages and disadvantages of adopting CBAF Frameworks, etc. This AR is a single-year (i.e. short-term) and single-university/single-country study, and therefore, a longitudinal and cross-universities/cross-countries AR study is needed to test the perceptions of taking CBAF compared to paper-and-pencil test over time. Finally yet importantly, AR is required to examine the impact student's profile (e.g. age, gender, nationality, etc.), study subjects (e.g. Management, Law, Maths and Computer Sciences, Medicine, Physics, etc.), academic performance, personal attitudes of using IT, study habits and leaning styles on preferring CBAF over paper-and-pencil exams and handwritten feedback. 


\section{Appendices}

\section{Appendix 1: the Syllabuses for the Accounting Modules used CBAF}

\section{Syllabus for Accounting Principles (Undergraduate Students: Year 1)}

1 - Introductions and some key conceptual tools, Users \& Accounting Equation

2- Double Entry Accounting \& Balance Sheet

3- The Income Statement

4- Accounting adjustments including Accruals and Prepayments

5- Published Accounts, Regulations and Basic Accounting Ratios including Profitability, Efficiency, Liquidity \& Investment Ratios

6- Financial Accounting Review and Introduction to Management Accounting

7- Classification of Costs, Cost behaviour, and Product Costs

8- Overhead Allocation and Absorption Costing,

9- Marginal Costing, Relevant Costs, and Decision Making

10- Break-Even Analysis and Budgeting

11- Introduction to Investment Appraisal

Syllabus for Intermediate Financial Accounting (Undergraduate Students: Year 2)

1- Preparation of financial statements

2- Statement of cash flows

3- Property, Plant and Equipment

4- Impairment of non-current assets

5- Intangible assets

6- Revenue recognition

7- Share capital

8- Construction contracts

9- Accounting for Leases

10- Taxation

11- Revision 
Syllabus for Advanced Financial Reporting (Undergraduate Students: Year 3)

1- Introduction and the Regulatory Framework

2- Consolidations - Financial position

3- Consolidations-Statement of comprehensive income

4- Consolidations- Post acquisition

5- Joint ventures and associates

6- Interpretation

7- Earnings per share

8- Earnings per share

9- Creative accounting

10- Accounting theory

11- Revision 


\section{Appendix 2: Examples of CBAFs \\ Examples of Accounting Principles $\mathrm{CBAF}$}

Question Title

Question

Answer

Correct Feedback

Incorrect Feedback

Feedforward

Question Title

Question

Answer

\section{Correct Feedback \\ Incorrect Feedback}

\section{Feedforward}

Question Title

Question

Answer

Correct Feedback

Incorrect Feedback

Feedforward

\section{Defining Accounting}

What does Accounting mean? Enter your answer below:

Accounting is the process of identifying, measuring, recording, and communicating economic information to the public to evaluate performance and make decision.

Excellent, your answer is correct. We also define accounting as the language of business, and the stakeholders can use this common business language to make judgements and taking investment decision.

Sorry, your answer is incorrect. Accounting is the process of identifying, measuring, recording, and communicating economic information to the public to evaluate performance and make decisions. It is also defined as the language of business.

Reference(s) to review: Lecture 1, tutorial 1, and Chapter 1, as seen in Lecture 1.

Income statement

This account does not appear on the income statement- select ONE response:

1. Marketing expense

2. Interest expense

3. Accumulated depreciation

4. Sales revenue

Well done, accumulated depreciation is not an expense or sales.

Sorry, accumulated depreciation is the correct answer. Marketing and interest expenses and sales revenue should appear in the income statement. While accumulated depreciation is a contra asset and should appear in the balance sheet.

Reference(s) to review: Lecture 3, tutorial 3 and relevant reading chapter(s), as seen in Lecture 3.

Financial Statements

Decide whatever the following statement is True or False: Income statement is another name for "the Profit and Loss Account".

True

False

True, it measures the profitability position and performance of the business unit for the previous 12 months.

Sorry, as it measures the profitability position and performance of the business unit for the previous 12 months, so it is the profit and loss account.

Reference(s) to review: Lecture 3, tutorial 3 and relevant reading chapter(s), as seen in Lecture 3. 
Question Title

Question

Answer

Correct Feedback

Incorrect Feedback

Feedforward

Question Title

Question

Answer

Correct Feedback

Incorrect Feedback

Feedforward

Question Title

Question

Answer

Correct Feedback

Incorrect Feedback

\section{Classifying Product/Service Costs}

Describe the three types of cost. Enter your answer below:

There are three types/classifications of product/service cost:

Direct and indirect cost; variable and fixed cost, and product and period cost.

Super, your answer is correct.

Sorry, your answer is incorrect. There are three types/classifications of product/service cost: Direct and indirect cost; variable and fixed cost, and product and period cost.

Reference(s) to review: Lecture 7, tutorial 7, and relevant reading Chapter, as seen in Lecture 7.

Total Assets

If a company has owners' equity of $£ 100,000$, so- select ONE response:

1. Total assets must equal $£ 100,000$

2. Assets minus liabilities equal $£ 100,000$

3. Net income for the past year was $£ 100,000$

4. A total of $£ 100,000$ was invested by the owner(s)

5. None of the above

Assets minus liabilities equal $£ 100,000$ is the correct answer for the total value of owners' equity. Total Owners' Equity = Assets - Liabilities, Well done!

Sorry, Assets minus liabilities equal $£ 100,000$ is the correct answer. According to accounting equation: Assets $=$ Liabilities + Equity Therefore, Equity $=$ Assets - Liabilities $=£ 100,000$

Reference(s) to review: Lecture $1 \& 2$, tutorial $1 \& 2$ and relevant reading chapter(s), as seen in Lecture $1 \& 2$.

Debtors Turnover

Carla Stores limited has the following items in its income statement And balance sheet at 31 December 2013:

$£$

Sales

$1,936,000$

Less: Cost of sales

$\underline{(1,027,435)}$

Gross profit

$\underline{908,565}$

Stocks

160,370

Debtors

226,485

Creditors

160,479

Calculate Debtors turnover ratio- select ONE response:

1. 57 days

2. 43 days

3. 43 times

4. None of the above

Well done, 43 days is the correct answer.

Debtors turnover in days $=$ Debtors/Sales x 365

$=(226,485 / 1,936,000) * 365=43$ days

Sorry, 43 days is the correct answer. 
Debtors turnover in days $=$ Debtors/Sales $\mathrm{x} 365$

$=(226,485 / 1,936,000) * 365=43$ days

Feedforward

Reference(s) to review: Lecture 5, tutorial 4, and relevant reading

chapter(s), as seen in Lecture 5.

\section{Examples of Intermediate Financial Accounting CBAF}

Question Title

Question

Answer

\section{Correct Feedback \\ Incorrect Feedback}

\section{Feedforward}

Question Title

Question

Answer

Correct Feedback

Incorrect Feedback

Feedforward

Question

Answer

Answer range +/Correct Feedback
Standard Setting Process

What are the main steps in the standard setting process? Enter your answer below:

. The main steps of setting a new standard are: 1) identification of the Application of the conceptual framework; 2) consultation with national standard Setters; 3) publication of discussion document and consideration of comments, 4) publication of exposure draft and consideration of comments, and 5) publication Of the approved draft of standard.

Marvellous, your answer is correct.

Sorry, your answer is incorrect. The main steps of setting a new standard are: 1) identification of the Application of the conceptual framework; 2) consultation with national standard Setters; 3) publication of discussion document and consideration of comments, 4) publication of exposure draft and consideration of comments, and 5) publication of the approved draft of standard.

Reference(s) to review: Lecture 1, tutorial 1, and relevant reading Chapter 1, as seen in Lecture 1.

Borrowing costs

In accordance with IAS 23 Borrowing Costs which of the following statements is true?

A. Borrowing costs can never be capitalised

B. Borrowing costs must always be capitalised

C. Borrowing costs in relation to intangible non-current assets must always be capitalised

D. Borrowing costs may be capitalised if they can be directly attributable To the acquisition, construction or production of a qualifying asset.

Good, if borrowing costs are part of the cost of acquisition, they must be included

Only when the costs are part of the acquisition costs, they must be included

Reference(s) to review: Lecture 3, tutorial 4, and relevant reading Chapter 10, as seen in Lecture 3.

On 31 March 2012 MDL net plc completes the handover of a new system to a client at an agreed price of $£ 1,600,000$. The price includes after-sales support for the next two years. The cost to MDL net of providing this support is estimated at $£ 96,000$ per annum, and the company earns a gross profit of $20 \%$ on similar support contracts. The customer pays the full $£ 1,600,000$ in May 2012. What is the value of the revenue to recognise for the sale upon the handover of the system in March 2012?

Enter a number do not use $£$ signs or commas

$1,360,000$

0

Well done: 
$\begin{array}{lr}\text { Annual cost of providing support } & 96,000 \\ \text { Profit element 20/80 x 96,000 } & 24,000 \\ \text { After-sales support revenue } & 120,000 \\ \text { Revenue to be recognised on handover of system } & 1,600,000 \\ \text { Price } & \underline{(240,000)} \\ \text { Less: } 2 \text { years of after-sales support revenue } & \underline{1,360,000}\end{array}$

\section{Incorrect Feedback}

\section{Feedforward}

\author{
Question Title \\ Question
}

Answer

\section{Correct Feedback \\ Incorrect Feedback}

Feedforward
The annual cost of providing support must be DEDUCTED from the sales figure. Thus $20 / 80$ of the at support is calculated thus:

Annual cost of providing support $\quad 96,000$

Profit element 20/80 x 96,000 $\underline{24,000}$

After-sales support revenue $\quad \underline{120,000}$

Revenue to be recognised on handover of system

Price

Less: 2 years of after-sales support revenue $\quad \underline{(240,000)}$

Reference(s) to review: Lecture 6, tutorial 7, and relevant reading Chapter 7, as seen in Lecture 6.

Sources of Accounting Regulations

What are the main sources of accounting regulations? Enter your answer below:

. The main sources of accounting regulations are: 1) National accounting Standards; 2) International accounting standards; 3) Company acts; 4) Governance regulations/codes; 5) Stock exchange regulations, etc.

Fabulous, your answer is correct.

Sorry, your answer is incorrect. The main sources of accounting regulations are:

1) National accounting standards; 2) International accounting standards;

3) Company Acts; 4) Governance regulations/codes; 5) Stock Exchange Regulations, etc.

Reference(s) to review: Lecture 1, tutorial 1, and relevant reading

Chapter 1, as seen in Lecture 1.

\section{Examples of Advanced Financial Reporting CBAF}

Question Title
Question

Answer

Correct Feedback

Incorrect Feedback

\section{Feedforward}

International Accounting Standards

Why are many UK \& Irish companies switching to IFRS? Enter your answer below:

. Companies in both UK \& Ireland adopted IFRS since 2005 following the EU Legal requirements, increasing legal requirements across the world to adopt IFRS, And increasing internationalisation of multinational businesses which needs for greater international uniformity, etc.

Wonderful, your answer is correct.

Sorry, your answer is incorrect. Companies in both UK \& Ireland adopted IFRS since 2005 following the EU legal requirements, increasing legal requirements across the world to adopt IFRS, and increasing internationalisation of multinational businesses which needs for greater international uniformity, etc. Reference(s) to review: Lecture 9, tutorial 9, and relevant reading Chapters, as seen in Lecture 9. 
Question

Answer

Correct Feedback

Incorrect Feedback

Feedforward

Question

Answer

Correct Feedback

Incorrect Feedback

Feedforward

Question Title

Question

Answer

Correct Feedback

Incorrect Feedback

Feedforward
Goodwill is measured as the difference between:

a. The difference between net assets and the loan capital of the business

b. The cost of acquisition and the acquirer's interest in the fair value of the net assets of the purchased entity

c. The cost of the acquisition and the discounted value of all assets

d. the fair value of the net assets of the business compared with the share capital

Good. Cost and interest in the value are the key

None are strictly accurate

Reference(s) to review: Lecture 3, tutorial 4, and relevant reading

chapter(s) 15 and 16, as seen in Lecture 3,4 and 5.

Which of the following is NOT an acceptable measurement basis for financial statement items:
a. Historic cost
b. Current cost
c. Realisable value
d. Future value

Good, all other measures can, and have been used.

Future value has never been used to measure items. It would be difficult to identify and verify the data

Reference(s) to review: Lecture 1, tutorial 2, and relevant reading Chapter(s) 1 and 2, as seen in Lecture $1 \& 2$.

Gross Profit

Explain why two companies carrying out identical trading transactions could produce different gross profit figures. Enter your answer below:

$\checkmark$. There are two reasons of having different gross profit for two companies with identical business transactions: 1) the method of evaluating inventory (Stocks) such as LIFO, FIFO or Weighed average, and 2) the recognition of revenue (sales).

Perfect, your answer is correct.

Sorry, your answer is incorrect. There are two reasons of having different gross profit for two companies with identical business transactions:

1) the method of evaluating inventory (Stocks) such as LIFO, FIFO or Weighted Average and 2) the recognition of revenue (sales).

Reference(s) to review: Lecture 2, tutorial 2, and relevant reading Chapters, as seen in Lecture 2.

\section{ACKNOWLEDGEMENTS}

I would like to thank Professor Alan Sangster (the Editor), Dr Steven Dellaportas (the Associate Editor), and the two anonymous reviewers for their insightful comments and suggestions on previous versions. I am also most grateful for helpful support and constructive comments provided by my colleagues: Mr James O’Neill, Mr Stephen Hicks and Mrs Tracy Clewlow. 


\section{References}

Abbott, J. \& Palatnik, B. (2018) Students' perceptions of their first accounting class: implications for instructors, Accounting Education, 27(1), 72-93.

Aisbitt, S. \& Sangster, A. (2005) Using internet-based online assessment: A case study, Accounting Education, 14 (4), 383-394.

Al-Htaybat, K. Alberti-Alhtayat, L. \& Alhatabat, Z. (2018) Education digital natives for the future: accounting educators' evaluation of the accounting, Accounting Education. DOI: 10.1080/09639284-2018.1437758.

Baker, C. \& Logan, L. (2006) Using action research to promote increased academic success for educationally disadvantaged students, Global Perspectives on Accounting Education, $3(1), 1-21$.

Barbera, E. (2009) Mutual feedback in e-portfolio assessment: An approach to the netfolio system, British Journal of Educational Technology, 40(2), 342-357.

Bennett, S. Maton, K. \& Kervin, L. (2008) The digital natives debate: a critical review of the evidence, British Journal of Educational Technology, 39(5), 775-786.

Beukes, B. Kirstein, M. Kunz, R. \& Nagel, L. (2017) Innovators to laggards- how South African students adopted and perceived technologically enhanced learning, Accounting Education. DOI: 10.1080/09639284.2017.1417875.

Brown, C. Baldwin-Morgan, A. \& Sangster, A. (1995) Expert systems in Accounting education- a literature review, Accounting Education: an international journal, 4(30, 283296.

Bullen, M. Morgan, T. \& Qayyum, A. (2011) Digital learners in higher education: Generation is not the issue, Canadian Journal of Learning and Technology, 37 (1), 1-24.

Carless, D. (2006) Differing perceptions in the feedback process, Studies in Higher Education, 31(2), 219-233.

Carr, W. \& Kemmis, S. (1986) Becoming Critical: Education, knowledge and action research (Lewis, Falmer).

Clariana, R. \& Wallace, P. (2002) Paper-based versus computer-based assessment: key factors associated with the test mode effect, British Journal of Educational Technology, 33(5), 593-602.

Cohen, L. Manion, L. \& Morrison, K. (2005) Research methods in Education (London, Routledge Publishers).

Cottrell. S. (2013) The Study Skills Handbook (Palgrave Macmillan Ltd). 
Crook, C. Gross, H. \& Dymott, R. (2006) Assessment relationships in higher education: the tension of process and practice, British Educational Research Journal, 32(1), 95-114.

Doran, J. Healy, M. McCutcheon, M. \& O’Callaghan, S. (2011) Adapting Case-Based Teaching to Large Class Settings: An Action Research Approach, Accounting Education, 20(3), 245-263.

Duff, A. (1998) Objectives tests, learning to learn and learning styles: a comment, Accounting Education, 7(4), 335-345.

Ecclestone, K. \& Pryor, J. (2003) Learning careers' or assessment careers? The impact of assessment systems on learning, British Educational Research Journal, 29, 471-488.

Elliot, J. (1991) Action Research for Educational Change (Buckingham: Open University Press).

Einig, S. (2013) Supportive Students' Learning: The Use of Formative Assessments, Accounting Education, 22(5), 425-444.

Evans, C. (2013) Making Sense of Assessment Feedback in Higher Education, Review of Educational Research, 83(1), 70-120.

Field, A. (2013) Discovering statistics using IBM SPSS statistics (London, Sage.

Gibbs, G. \& Simpson, C. (2005) Conditions under which assessment supports students' learning, Journal of Learning and Teaching in Higher Education, 1, 3-31.

Gros, B. Garcia, I. \& Escofet, A. (2012) Beyond the Net Generation Debate: A Comparison of Digital Learners in Face-to-Face and Virtual Universities, The International Review of Research in Open and Distance Learning, 13(4), 190-210.

Hattie, J. \& Timperley, H. (2007) The power of feedback, Review of Educational Research, 77(1), 81-112.

Helsper, E. \& Eynon, R. (2010) Digital natives: where is the evidence? British Educational Research Journal, 36(3), 503-520.

Hughes, R. (1997) What is action research? Available online at: www.scu.edu.au/schools/gcm/ar/arr/arow/rintro.html (accessed 15 June 2015).

Jebeile, S. \& Abeysekera, I. (2010) The spread of ICT innovation in accounting education, International Journal of Teaching and Learning in Higher Education, 22(2), 158-168.

JISC (Joint Information Systems Committee) (2007) Effective Practice with e-Assessment: An overview of technologies, policies and practice in further and higher education. Available online at: $\underline{w w w . j i s c . a c . u k / a s s e s s r e s o u r c e ~(a c c e s s e d ~} 15$ July 2015).

JISC (Joint Information Systems Committee) (2010) Effective Assessment in a Digital Age. Available online at: $\underline{w w w . j i s c . a c . u k / a s s e s s r e s o u r c e ~(a c c e s s e d ~} 15$ July 2015). 
Jones, C. Ramanau, R. Cross, S. \& Healing, G. (2010) Net Generation or digital natives: Is there a distinct new generation entering university?, Computers and Education, 54(3),722732.

Kember, D. \& Young, D. (2006) Characterising a teaching and learning environment conducive to making demands on students while not making their workload excessive, Studies in Higher Education, 31,185-198.

Kember, D. (2000) Reflective teaching and learning in the health professions: action research in professional education (Oxford, Blackwell Science Publishers).

Kirkwood, A. \& Price, L. (2005) Learners and learning in the 21st century: What do we know about students' attitudes and experiences of ICT that will help us design courses? Studies in Higher Education, 30(3), 257-274.

Lee, J. (1986) The effects of past computer experience on computerized aptitude test performance, Educational and Psychological Measurement, 46, 727-733.

Litherland, K. Carmichael, P. \& Martinez-Garcia, A. (2013) Ontology-based e-Assessment for Accounting Education, Accounting Education, 22(5), 498-501.

Loewenberger, P. \& Bull, J. (2003) Cost-effectiveness of computer-based assessment, The Journal of the Association for Learning Technology, 11(2), 23-45.

Marriott, P. (2009) Students' evaluation of the use of online summative assessment on an undergraduate financial accounting module, British Journal of Educational Technology, 40(2), 237-254.

Marriott, P. \& Lau, A. (2008) The use of on-line summative assessment in an undergraduate financial accounting course, Journal of Accounting Education, 26, 73-90.

Marriott, P. \& Teoh, L. (2012a) ICT for assessment and feedback on undergraduate accounting modules. Available online at: http://www.heacademy.ac.uk/resources/detail/disciplines/finance-and-accounting/using-ICTin-assessment-and-feedback (accessed 10 July 2015).

Marriott, P. \& Teoh, L. (2012b) Computer-based assessment and feedback: Best Practice Guidelines. Available online at: http://www.heacademy.ac.uk/assets/documents/disciplines/finance_and_accounting/Compute r-basedassessmentfeedbackBestPractice.pdf (accessed 10 July 2015).

Massoudi, D. Koh, S. Hancock, P. \& Fung, L. (2017) The Effectiveness of Usage of Online Multiple Choice Questions on Student Performance in Introductory Accounting, Issues in Accounting Education, 32(4), 1-17.

McDonald, A. (2002) The impact of individual differences on the equivalence of computerbased and paper-and-pencil educational assessments, Computers \& Education, 39, 299-312.

McNiff, J. (1988) Action Research-Principles and Practice, (London, Routledge). 
Mihret, D. Abayadeera, N. Watty, K. \& McKay, J. (2017) Teaching auditing using cases in an online learning environment: the role of ePortfolio assessment, Accounting Education, 26(4), 335-357.

Nguyen, T. Charity, I. \& Robson, A. (2016) Students' perceptions of computer-based learning environments, their attitude towards business statistics, and their academic achievement: implications from a UK university, Studies in Higher Education, 41(4), 734755.

Oblinger, D. \& Oblinger, J. (2005) Educating the Net Generation. Available online at: www.educause.edu/ir/library/pdf/pub7101.pdf (accessed 7 June 2015.

O'connell, B. Ferguson, C. De Lange, P. Howieson, B. Watty, K. Carr, R. Jacobson, B. Campitelli, L. Gora, Y. Milton, A. (2010) Enhancing Assessment Feedback: Practices in Accounting Education: Issues, Obstacles and Reforms. Available online at: http://www.olt.gov.au/project-enhancing-assessment-feedback-practices-jcu-2007 (accessed 10 June 2015).

Paisey, C. \& Paisey, N. (2004) An analysis of accounting education research in Accounting Education: an international journal- 1992-2001, Accounting Education, 13(1), 69-99.

Paisey, C. \& Paisey, N. (2003) Developing research awareness in students: an action research project explored, Accounting Education, 12(3), 283-302.

Pincus, K. Stout, D. Sorensen, J. Stocks, K. \& Lawson, R. (2017) Forces for change in higher education and implications for the accounting academic, Journal of Accounting Education, 40, 1-18.

Potter, B. \& Johnston, C. (2006) The effect of interactive on-line learning systems on student learning outcomes in accounting, Journal of Accounting Education, 24,16-34.

Powers, E. (1999) Test anxiety and test performance: comparing paper-based and computeradaptive versions of the GRE general test (Princeton, NJ: Educational Testing Service).

Pryor, J. \& Crossouard, B. (2008) A socio-cultural theorisation of formative assessment, Oxford Review of Education, 34(1), 1-20.

QAA (2009) Academic credit in higher education in England- an introduction. The Quality Assurance Agency for Higher Education. Available online at: www.qaa.ac.uk (accessed 20 March 2017).

Race, P. (2005) Making learning happen: a guide for post-compulsory education (London, SAGE Publications).

Rowe, A. \& Wood, L. (2008) Student Perceptions and Perceptions for Feedback, Asian Social Science, 4(3), 78-88. 
Rodrigues, L. Pinho, C. Bugarim, M. Craig, R. \& Machado, D. (2018) Factors affecting success in the professional entry exam for accountants in Brazil, Accounting Education, 27(1), 48-71.

Rust, C. O'Donovan, B. \& Price, M. (2005) A social constructivist assessment process model: how the research literature shows us this could be best practice, Assessment and Evaluation in Higher Education, 30, 231-240.

Sadler, D. (1989) Formative assessment and the design of instructional systems, Instructional Science, 18, 119-144.

Sangster, A. (1992) Computer-based instruction in accounting education, Accounting Education, 1(1), 13-32.

Sangster, A. (1995) The integration of expert systems within the accounting curriculum, Accounting Education, 4(3), 211-216.

Sangster, A. (1996) Objective tests, learning to learn and learning styles, Accounting Education, 5(1), 131-146.

Sangster, A. \& McCombie, I. (1993) How well do accountancy students understand a set of accounts? Accounting Education: an international journal, 2(1), 53-62.

Sangster, A. \& Mulligan, C. (1997) Integrating the World Wide Web into an accounting systems course, Accounting Education, 6(1), 53-62.

Sangster, A. \& Lymer, A. (1998) How to Survive a New Educational Era, Issues in Accounting Education, 13(4), 1095-1109.

Sangster, A. \& Wilson, R. (1991) Knowledge-based learning within the accounting curriculum, British Accounting Review, 23, 243-261.

Saunders, M. Lewis, P. \& Thornhill, A. (2009) Research Methods For Business Students, (England, Pearson Education).

Simin, S. \& Heidari, A. (2013) Computer-based assessment: pros and cons, Educational Technology, 55, 12732-12734.

Taylor, C. Kirsch, I., Eignor, D. \& Jamieson, J. (1999) Examining the relationship between computer familiarity and performance on computer-based language tasks, Language Learning, 49(2), 219-274.

Thelwall, M. (2000) Computer-based assessment: a versatile educational tool, Computer \& Education, 34, 37-49.

Timmis, S. Broadfoot, P. Sutherland, R. \& Oldfield, A. (2016) Rethinking assessment in a digital age: opportunities, challenges and risks, British Educational Research Journal, 42(3), 454-476. 
Torrance, H. \& Pryor, J. (2001) Developing formative assessment in the classroom: Using action research to explore and modify theory, British Educational Research Journal, 26, 615631.

Van der Kleij, F. Feskens, R. \& Eggen, T. (2015). Effects of Feedback in a Computer-Based Learning Environment on Students' Learning Outcomes: A Meta-Analysis, Review of Educational Research, 85(4), 475-511.

Wong, L. (2009) E-assessment: its implementation and impact on learning outcomes, Journal of Applied Research in Higher Education, 1(1), 50-60. 